\title{
LEVEL II SCOUR ANALYSIS FOR BRIDGE 7 (WALDTH00020007) on TOWN HIGHWAY 2, crossing COLES BROOK, WALDEN, VERMONT
}

U.S. Geological Survey Open-File Report 97-632

Prepared in cooperation with

VERMONT AGENCY OF TRANSPORTATION and

FEDERAL HIGHWAY ADMINISTRATION 


\section{LEVEL II SCOUR ANALYSIS FOR BRIDGE 7 (WALDTH00020007) on TOWN HIGHWAY 2, crossing COLES BROOK, WALDEN, VERMONT \\ By LORA K. STRIKER AND LAURA MEDALIE \\ U.S. Geological Survey Open-File Report 97-632}

Prepared in cooperation with

VERMONT AGENCY OF TRANSPORTATION

and

FEDERAL HIGHWAY ADMINISTRATION 


\title{
U.S. DEPARTMENT OF THE INTERIOR BRUCE BABBITT, Secretary
}

\author{
U.S. GEOLOGICAL SURVEY \\ Gordon P. Eaton, Director
}

For additional information write to:

District Chief

U.S. Geological Survey 361 Commerce Way

Pembroke, NH 03275-3718
Copies of this report may be purchased from:

U.S. Geological Survey

Branch of Information Services

Open-File Reports Unit

Box 25286

Denver, CO 80225-0286 


\section{CONTENTS}

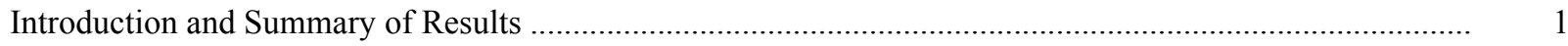

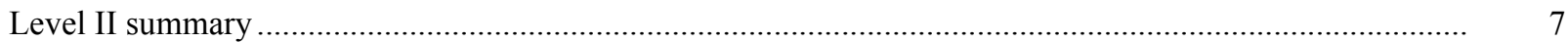

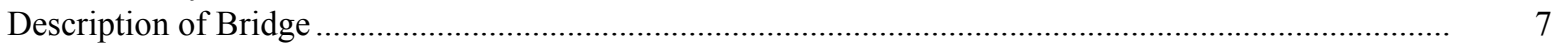

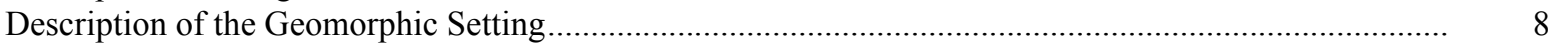

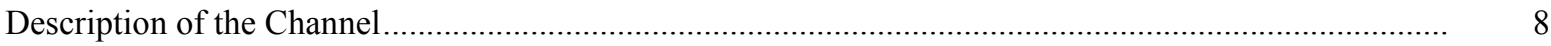

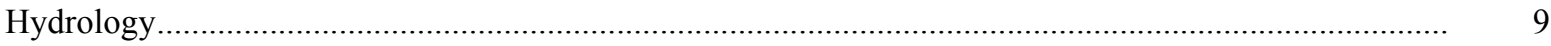

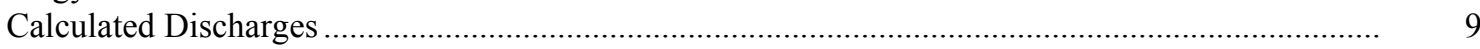

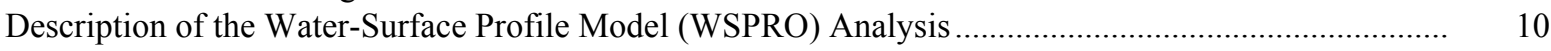

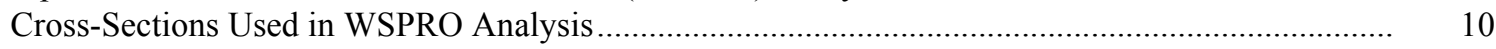

Data and Assumptions Used in WSPRO Model ...................................................................... 11

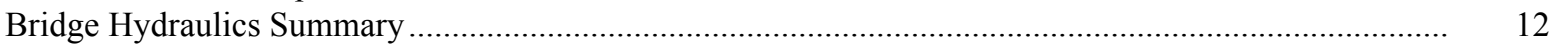

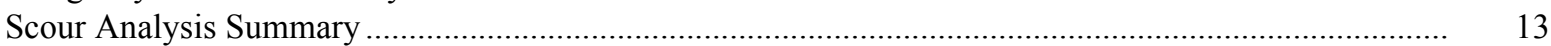

Special Conditions or Assumptions Made in Scour Analysis ...................................................... 13

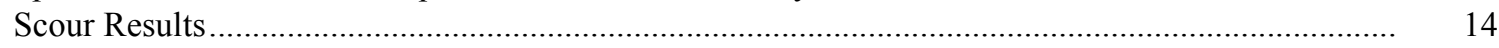

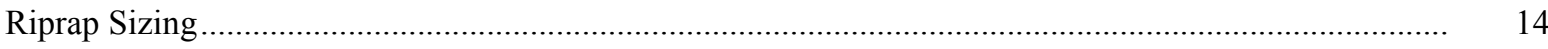

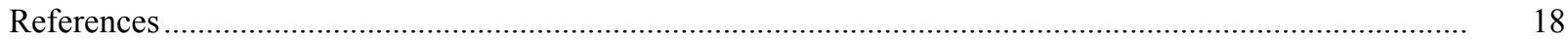

Appendixes:

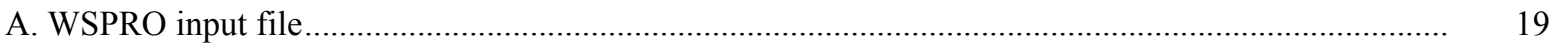

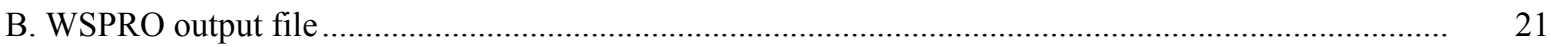

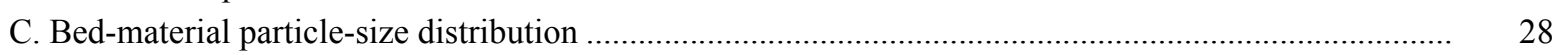

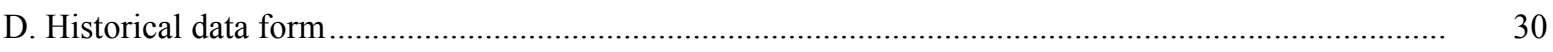

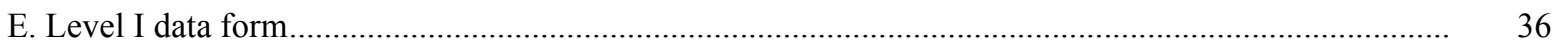

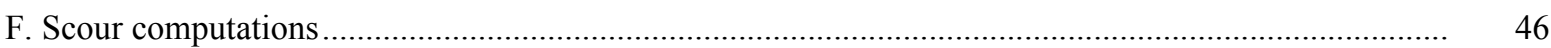

\section{FIGURES}

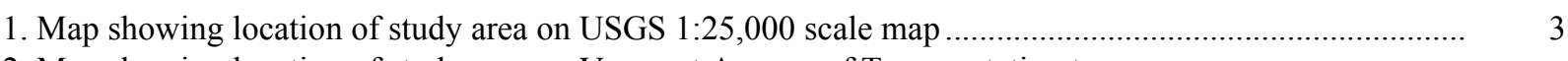

2. Map showing location of study area on Vermont Agency of Transportation town
highway map

3. Structure WALDTH00020007 viewed from upstream (August 9, 1995) ................................................ 5

4. Downstream channel viewed from structure WALDTH00020007 (August 9, 1995)............................ 5

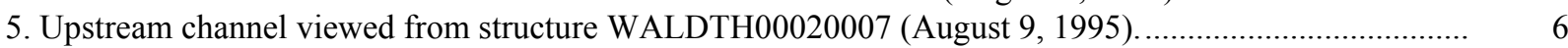

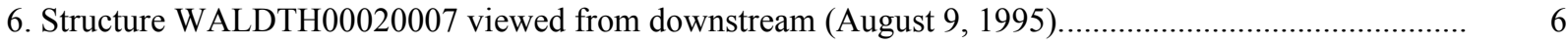

7. Water-surface profiles for the 100- and 500-year discharges at structure

WALDTH00020007 on Town Highway 2, crossing Coles Brook,

Walden, Vermont.

8. Scour elevations for the 100- and 500-year discharges at structure

WALDTH00020007 on Town Highway 2, crossing Coles Brook,

Walden, Vermont.

\section{TABLES}

1. Remaining footing/pile depth at abutments for the 100-year discharge at structure

WALDTH00020007 on Town Highway 2, crossing Coles Brook,

Walden, Vermont

2. Remaining footing/pile depth at abutments for the 500-year discharge at structure

WALDTH00020007 on Town Highway 2, crossing Coles Brook,

Walden, Vermont

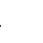

5

6

(n)
(5) 


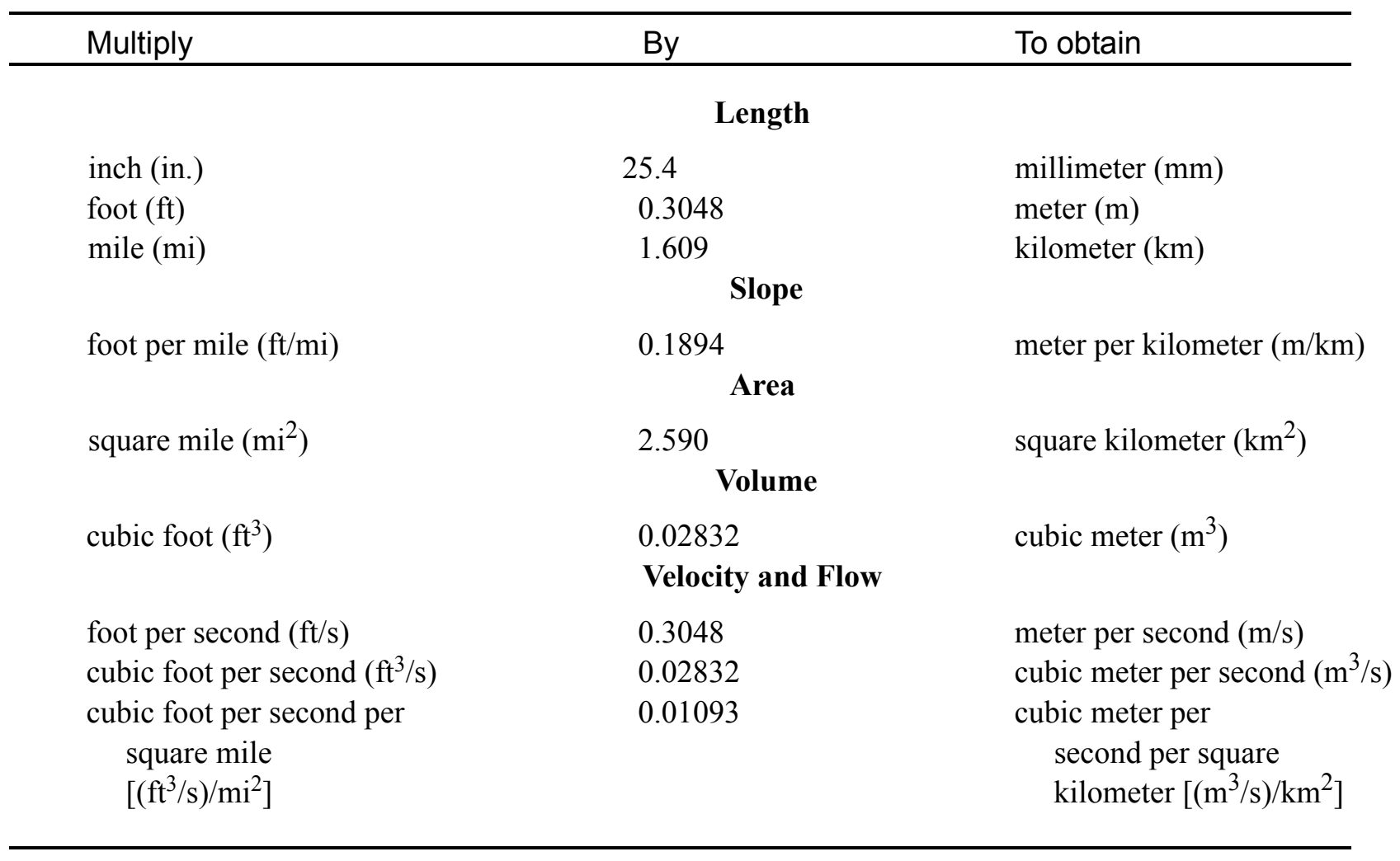

\section{OTHER ABBREVIATIONS}

$\begin{array}{lrlr}\mathrm{BF} & \text { bank full } & \text { LWW } & \text { left wingwall } \\ \mathrm{cfs} & \text { cubic feet per second } & \text { MC } & \text { main channel } \\ \mathrm{D}_{50} & \text { median diameter of bed material } & \text { RAB } & \text { right abutment } \\ \mathrm{DS} & \text { downstream } & \text { RABUT } & \text { face of right abutment } \\ \mathrm{elev} & \text { elevation } & \text { RB } & \text { right bank } \\ \mathrm{f} / \mathrm{p} & \text { flood plain } & \text { ROB } & \text { right overbank } \\ \mathrm{ft}^{2} & \text { square feet } & \text { RWW } & \text { right wingwall } \\ \mathrm{ft} / \mathrm{ft} & \text { feet per foot } & \text { TH } & \text { town highway } \\ \mathrm{JCT} & \text { junction } & \text { UB } & \text { under bridge } \\ \mathrm{LAB} & \text { left abutment } & \text { US } & \text { upstream } \\ \mathrm{LABUT} & \text { face of left abutment } & \text { USGS } & \text { United States Geological Survey } \\ \mathrm{LB} & \text { left bank } & \text { VTAOT Vermont Agency of Transportation } \\ \mathrm{LOB} & \text { left overbank } & \text { WSPRO } & \text { water-surface profile model }\end{array}$

In this report, the words "right" and "left" refer to directions that would be reported by an observer facing downstream. Sea level: In this report, "sea level" refers to the National Geodetic Vertical Datum of 1929-- a geodetic datum derived from a general adjustment of the first-order level nets of the United States and Canada, formerly called Sea Level Datum of 1929.

In the appendices, the above abbreviations may be combined. For example, USLB would represent upstream left bank. 


\title{
LEVEL II SCOUR ANALYSIS FOR BRIDGE 7 (WALDTH00020007) ON TOWN HIGHWAY 2, CROSSING COLES BROOK, WALDEN, VERMONT
}

\author{
By Lora K. Striker and Laura Medalie
}

\section{INTRODUCTION AND SUMMARY OF RESULTS}

This report provides the results of a detailed Level II analysis of scour potential at structure WALDTH00020007 on Town Highway 2 crossing Coles Brook, Walden, Vermont (figures $1-8)$. Coles Brook is also referred to as Joes Brook. A Level II study is a basic engineering analysis of the site, including a quantitative analysis of stream stability and scour (U.S. Department of Transportation, 1993). Results of a Level I scour investigation also are included in Appendix E of this report. A Level I investigation provides a qualitative geomorphic characterization of the study site. Information on the bridge, gleaned from Vermont Agency of Transportation (VTAOT) files, was compiled prior to conducting Level I and Level II analyses and is found in Appendix D.

The site is in the New England Upland section of the New England physiographic province in north-eastern Vermont. The $12.8-\mathrm{mi}^{2}$ drainage area is in a predominantly rural and forested basin. In the vicinity of the study site, the surface cover is predominantly shrub and brushland.

In the study area, Coles Brook has a sinuous channel with a slope of approximately $0.005 \mathrm{ft} /$ $\mathrm{ft}$, an average channel top width of $37 \mathrm{ft}$ and an average bank height of $4 \mathrm{ft}$. The channel bed material ranges from sand to cobble with a median grain size $\left(\mathrm{D}_{50}\right)$ of $32.9 \mathrm{~mm}(0.108 \mathrm{ft})$. The geomorphic assessment at the time of the Level I and Level II site visit on August 9, 1995 , indicated that the reach was laterally unstable due to cut-banks, point bars, and loose unconsolidated bed material.

The Town Highway 2 crossing of Coles Brook is a 74-ft-long, two-lane bridge consisting of one 71-foot steel-beam span (Vermont Agency of Transportation, written communication, April 5, 1995). The opening length of the structure parallel to the bridge face is $69.3 \mathrm{ft}$. The bridge is supported by spill-through abutments. The channel is skewed approximately 35 degrees to the opening while the measured opening-skew-to-roadway is 15 degrees. 
A scour hole $1.5 \mathrm{ft}$ deeper than the mean thalweg depth was observed from $60 \mathrm{ft}$. to $100 \mathrm{ft}$. downstream during the Level I assessment. Scour protection measures at the site include: type-1 stone fill (less than 12 inches diameter) along the right bank upstream, at the downstream end of the downstream left wingwall and downstream right wingwall; and type-2 stone fill (less than 36 inches diameter) along the left bank upstream, at the upstream end of the upstream right wingwall, and along the entire base of the left and right abutments. Additional details describing conditions at the site are included in the Level II Summary and Appendices D and E.

Scour depths and recommended rock rip-rap sizes were computed using the general guidelines described in Hydraulic Engineering Circular 18 (Richardson and others, 1995). Total scour at a highway crossing is comprised of three components: 1) long-term streambed degradation; 2) contraction scour (due to accelerated flow caused by a reduction in flow area at a bridge) and; 3 ) local scour (caused by accelerated flow around piers and abutments). Total scour is the sum of the three components. Equations are available to compute depths for contraction and local scour and a summary of the results of these computations follows.

Contraction scour for all modelled flows ranged from 0.0 to $0.8 \mathrm{ft}$. The worst-case contraction scour occurred at the incipient roadway-overtopping discharge. Abutment scour ranged from 5.7 to $12.9 \mathrm{ft}$. The worst-case abutment scour occurred at the 500 -year discharge. Additional information on scour depths and depths to armoring are included in the section titled "Scour Results". Scoured-streambed elevations, based on the calculated scour depths, are presented in tables 1 and 2. A cross-section of the scour computed at the bridge is presented in figure 8 . Scour depths were calculated assuming an infinite depth of erosive material and a homogeneous particle-size distribution.

It is generally accepted that the Froehlich equation (abutment scour) gives "excessively conservative estimates of scour depths" (Richardson and others, 1995, p. 47). Usually, computed scour depths are evaluated in combination with other information including (but not limited to) historical performance during flood events, the geomorphic stability assessment, existing scour protection measures, and the results of the hydraulic analyses. Therefore, scour depths adopted by VTAOT may differ from the computed values documented herein. 


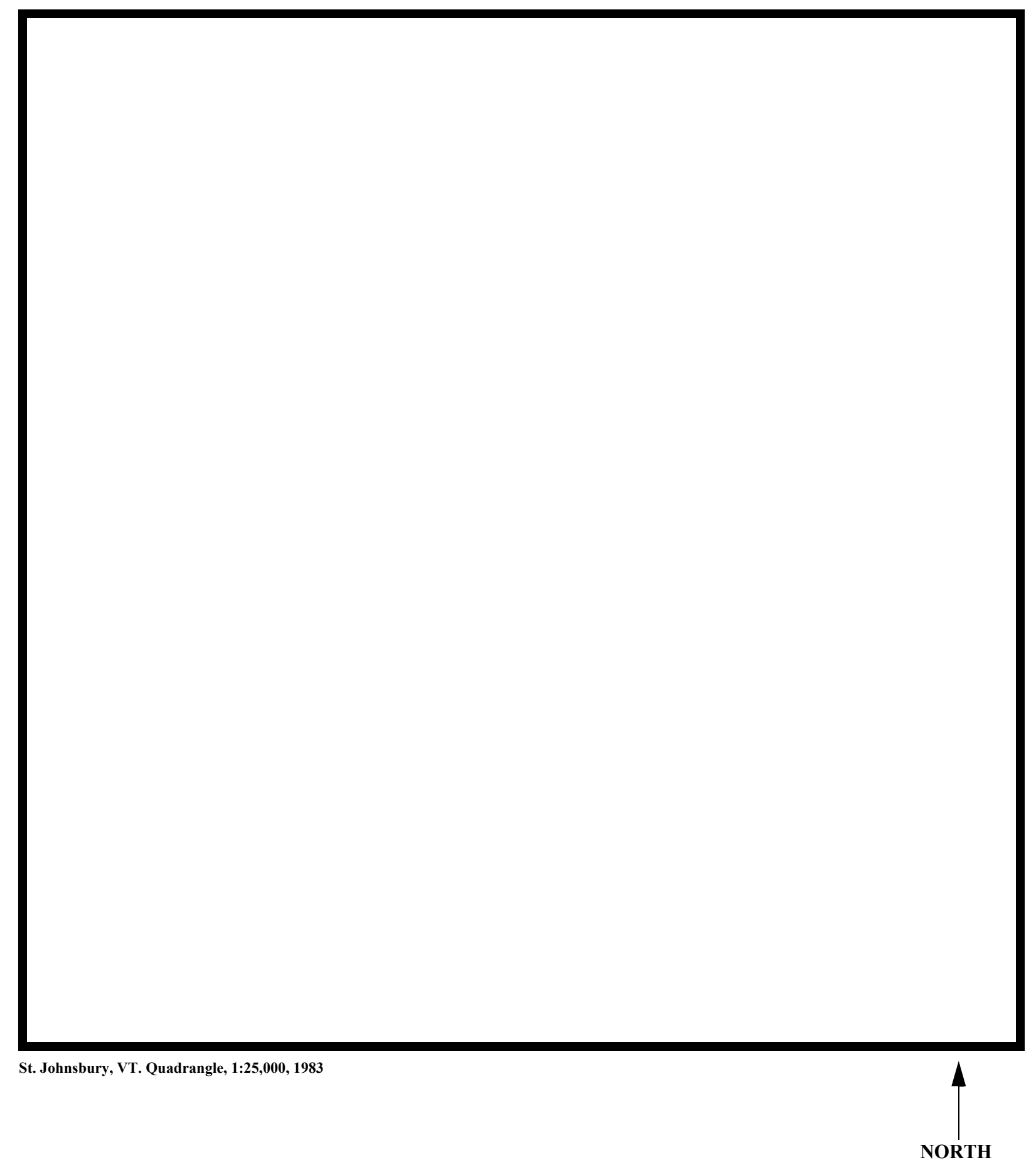

Figure 1. Location of study area on USGS 1:25,000 scale map. 
Figure 2. Location of study area on Vermont Agency of Transportation town highway map. 

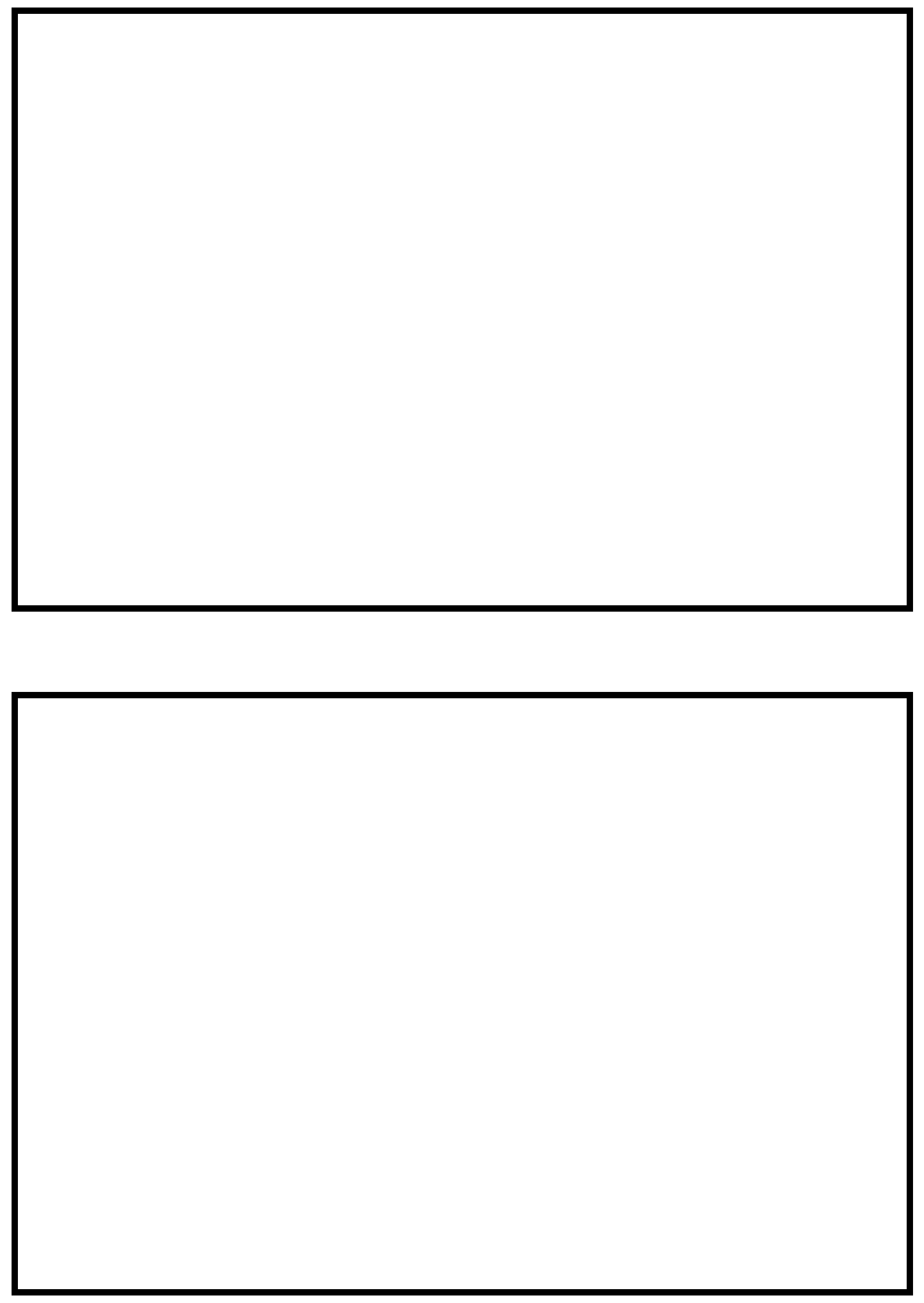

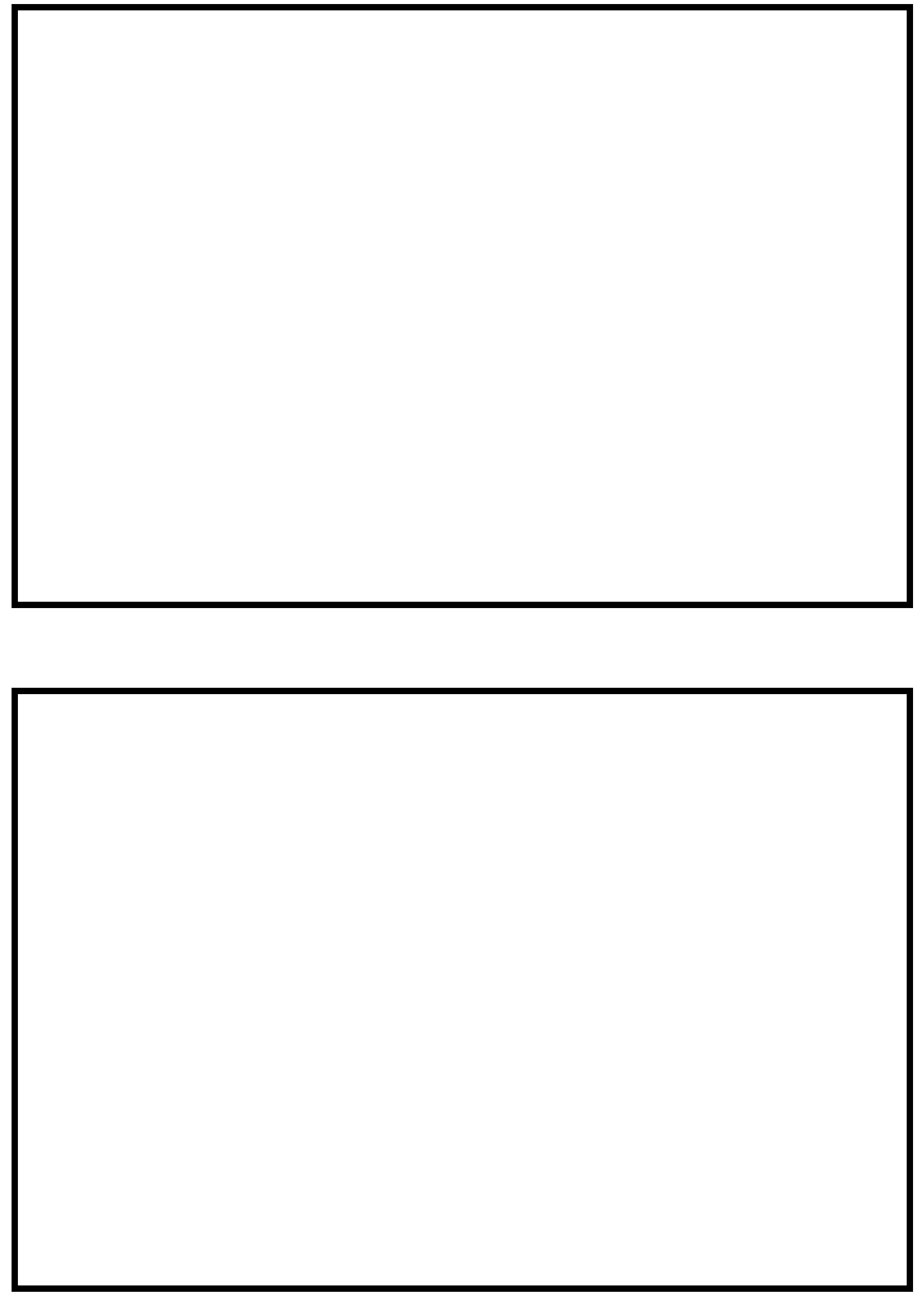


\section{LEVEL II SUMMARY}

\begin{tabular}{lllllll} 
Structure Number & WALDTH00020007 & Stream & \multicolumn{2}{c}{ Coles Brook } & \\
& Sounty & Caledonia & Road & TH 2 & District & 7
\end{tabular}

\section{Description of Bridge}

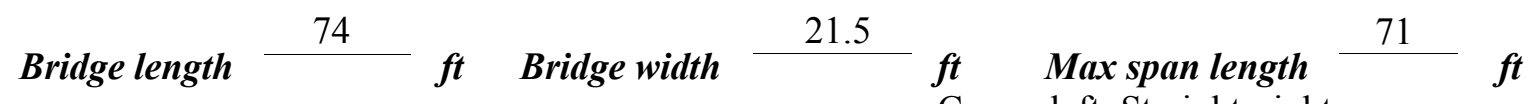

Alignment of bridge to road (on curve or straight) spill through

Abutment type

Yes

Stone fill on abutment?

Yes

Embankment type

Curve, left; Straight, right

Sloping

08/09/95

Dasmintin.. af atan a fill

Type-2, laid rip rap forming spill through abutments show no evidence of scour. Both abutments have undermined areas.

Abutments are spill through. Stub abutments are

concrete with sloping spillthroughs composed of fill and large placed rip rap.

\section{Y}

35

Is bridge skewed to flood flow according to Y Y survey?

Angle

There is a mild channel bend at the bridge. A point bar has developed along the right abutment and inside bend of the right abutment.

Debris accumulation on bridge at time of Level I or Level II site visit:

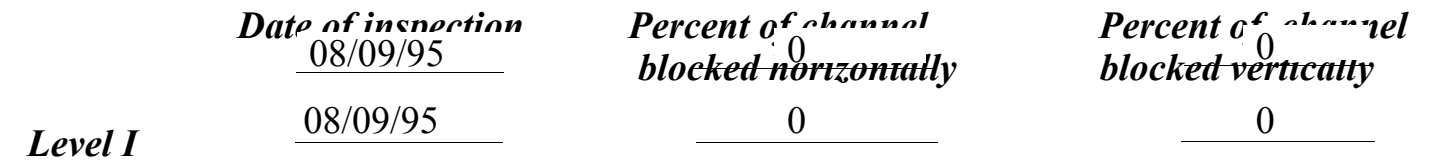

Level II

Low. There are a few scattered logs in stream from recent flooding.

Debris is caught at bridge in I-beams from flood of 08/05/95.

Potential for debris

$08 / 09 / 95$, There is a beaver dam located more than one bridge length downstream of the bridge

Dosrriho anv fonturos noar or at tho hridos that mav affort flow, (includo ahsoryation dato) that may cause backwater to the site. 


\section{Description of the Geomorphic Setting}

General topography The channel is located within a low relief valley with narrow flood plains. 08/09/95

Geomorphic conditions at bridge site: downstream (DS), upstream (US)

Date of inspection Moderately

DS left: $\quad$ sloped overbank

DS right: $\quad$ Narrow flood plain

US left: $\quad$ Steep channel bank to a narrow flood plain

US right: $\quad$ Moderately sloped overbank

\section{Description of the Channel}

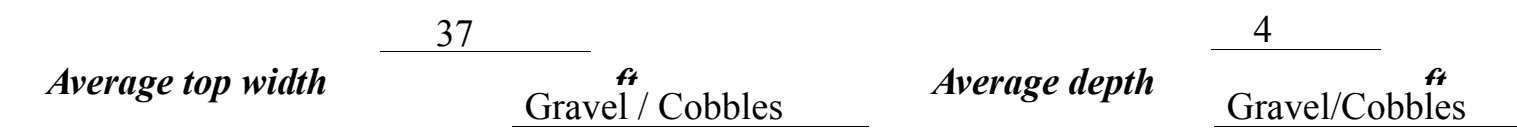

Predominant bed material Bank material Sinuous and laterally

unstable with semi-alluvial channel boundaries and narrow floö pläns.

$08 / 09 / 95$

Vegetative col Shrubs and brush

DS left: $\quad$ Shrubs and brush

DS right: $\quad$ Shrubs and brush

US left: $\quad$ Shrubs and brush

US right: $\quad$ No

Do banks appear stable? Lateral instability in the channel is indicated by cut-banks woint bars, dand loose unconsolidated bed material, 08/09/95.

None as of 08/09/95,

There is a beaver dam located more than one bridge length downstream of the bridge that may Describe any obstructions in channel and date of observation.

be causing backwater to the site. 


\title{
Hydrology
}

Drainage area $\frac{12.8}{\boldsymbol{m i}^{2}}$

Percentage of drainage area in physiographic provinces: (approximate)

Physiographic province/section New England/New England Upland
Percent of drainage area 100

\begin{abstract}
Is drainage area considered rural or urban?
Rural None.

urbanization:-

Describe any significant
\end{abstract}

Is there a USGS gage on the stream of interest?

No

USGS gage description

USGS gage number

Gage drainage area $\mathrm{mi}^{2}$

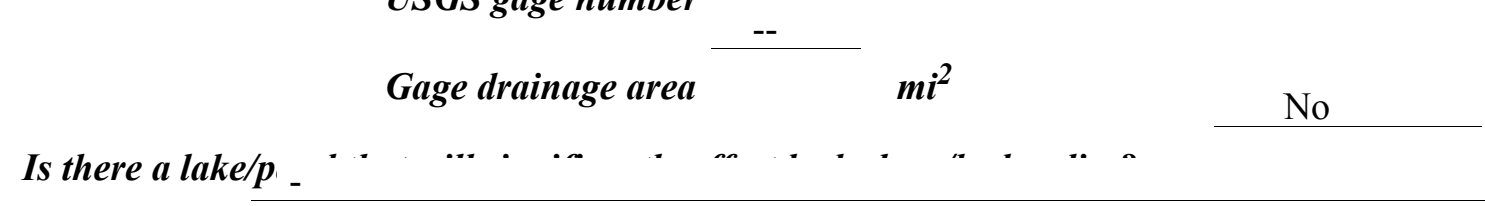

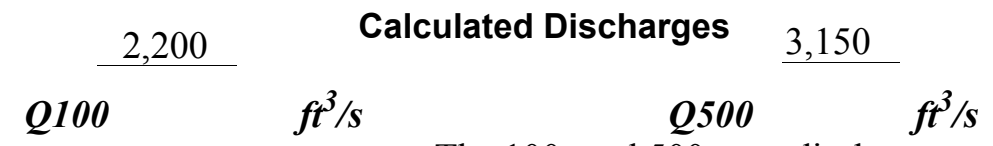

The 100- and 500-year discharges are based on a

drainage area relationship.[(12.8/16.4)exp 0.67] with bridge number 83 in Walden. Bridge number 83 crosses Coles Brook downstream of this site and has flood frequency estimates available from the VTAOT database which were graphically extrapolated to the 500-year discharge. The drainage area above bridge number 83 is 16.4 square miles. The discharges used were in the range of empirical methods. (Benson, 1962; Johnson and Tasker, 1974; FHWA, 1983; Potter, 1957a\&b; Talbot, 1887) 


\section{Description of the Water-Surface Profile Model (WSPRO) Analysis}

Datum for WSPRO analysis (USGS survey, sea level, VTAOT plans)

USGS survey

Datum tie between USGS survey and VTAOT plans

None

Description of reference marks used to determine USGS datum. $\quad$ RM1 is a chiseled X on top of the downstream end of the left abutment (elev. $499.04 \mathrm{ft}$, arbitrary survey datum). RM2 is a chiseled X on top of the upstream end of the right abutment (elev. $499.76 \mathrm{ft}$, arbitrary survey datum).

\section{Cross-Sections Used in WSPRO Analysis}

\begin{tabular}{cccl}
\hline${ }^{1}$ Cross-section & $\begin{array}{c}\text { Section } \\
\text { Reference } \\
\text { Distance } \\
\text { (SRD) } \text { in feet }\end{array}$ & $\begin{array}{c}{ }^{2} \text { Cross-section } \\
\text { development }\end{array}$ & \multicolumn{1}{c}{ Comments } \\
\hline EXITX & -94 & 1 & Exit section \\
FULLV & 0 & 2 & $\begin{array}{l}\text { Downstream Full-valley } \\
\text { section (Templated from } \\
\text { EXITX) }\end{array}$ \\
BRIDG & 0 & 1 & Bridge section \\
RDWAY & 12 & 1 & Road Grade section \\
APPRO & 90 & 1 & Approach section \\
\hline
\end{tabular}

${ }^{1}$ For location of cross-sections see plan-view sketch included with Level I field form, Appendix E. For more detail on how cross-sections were developed see WSPRO input file. 


\section{Data and Assumptions Used in WSPRO Model}

Hydraulic analyses of the reach were done by use of the Federal Highway Administration's WSPRO step-backwater computer program (Shearman and others, 1986, and Shearman, 1990). The analyses reported herein reflect conditions existing at the site at the time of the study. Furthermore, in the development of the model it was necessary to assume no accumulation of debris or ice at the site. Results of the hydraulic model are presented in the Bridge Hydraulic Summary, Appendix B, and figure 7.

Channel roughness factors (Manning's “ $n$ ”) used in the hydraulic model were estimated using field inspections at each cross section following the general guidelines described by Arcement and Schneider (1989). Final adjustments to the values were made during the modelling of the reach. Channel " $n$ " values for the reach ranged from 0.040 to 0.055 , and overbank " $n$ " values were 0.070 .

Normal depth at the exit section (EXITX) was assumed as the starting water surface. This depth was computed by use of the slope-conveyance method outlined in the user's manual for WSPRO (Shearman, 1990). The slope used was $0.0046 \mathrm{ft} / \mathrm{ft}$ which was estimated from the topographic map (U.S. Geological Survey, 1983).

The surveyed approach section (APPRO) was surveyed one bridge length upstream of the upstream face as recommended by Shearman and others (1986). This location provides a consistent method for determining scour variables. 


\section{Bridge Hydraulics Summary}

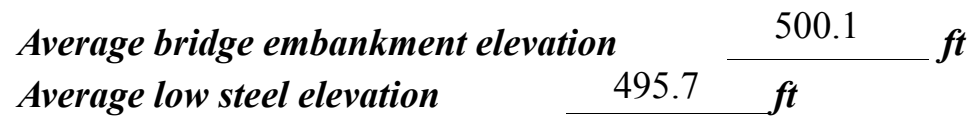

100-year discharge $\quad 2,220 \quad \mathrm{ft}^{3} / \mathrm{s}$

Water-surface elevation in bridge opening $\quad 493.4 \quad f t$

Road overtopping? ___ N Discharge over road __ $\quad$\begin{tabular}{lll}
$\mathrm{ft}^{3} / \mathrm{s}$ \\
\hline
\end{tabular}

\begin{tabular}{lll} 
Area of flow in bridge opening & $270 \quad \boldsymbol{f t}^{2}$ \\
\cline { 2 - 3 } Average velocity in bridge opening & 8.2 & $\mathrm{ft} / \mathrm{s}$
\end{tabular}

$\begin{array}{llll}\text { Maximum WSPRO tube velocity at bridge } & 9.9 & \mathrm{ft} / \mathrm{s}\end{array}$

Water-surface elevation at Approach section with bridge 495.3

Water-surface elevation at Approach section without bridge $\quad 494.0$

Amount of backwater caused by bridge $\quad 1.3$ it

500-year discharge $\quad 3,150 \quad \mathrm{ft}^{3} / \mathrm{s}$

Water-surface elevation in bridge opening $\quad 496.0 \mathrm{ft}$

Road overtopping? ___ Y Discharge over road ___ $107^{-}$

\begin{tabular}{llll} 
Area of flow in bridge opening & 424 & $\boldsymbol{f t}^{2}$ & \\
\cline { 3 - 4 } Average velocity in bridge opening & & 7.2 & $\boldsymbol{f t} / \mathbf{s}$ \\
Maximum WSPRO tube velocity at bridge & & $8.4 \quad$ 's
\end{tabular}

Water-surface elevation at Approach section with bridge 497.0

Water-surface elevation at Approach section without bridge $\quad 494.6$

Amount of backwater caused by bridge $\quad 2.4$.t

Incipient overtopping discharge $\quad 2,540 \quad \mathrm{ft}^{3} / \mathrm{s}$

Water-surface elevation in bridge opening $493.6 \quad t$

Area of flow in bridge opening $\quad 279 \quad \mathrm{ft}^{2}$

Average velocity in bridge opening $\quad 9.1 \quad \mathrm{ft} / \mathrm{s}$

Maximum WSPRO tube velocity at bridge $11.0 \mathrm{ft} / \mathrm{s}$

Water-surface elevation at Approach section with bridge

Water-surface elevation at Approach section without bridge

495.9

Amount of backwater caused by bridge $\quad 1.7$.t

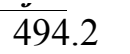




\section{Scour Analysis Summary}

\section{Special Conditions or Assumptions Made in Scour Analysis}

Scour depths were computed using the general guidelines described in Hydraulic Engineering Circular 18 (Richardson and others, 1995). Scour depths were calculated assuming an infinite depth of erosive material and a homogeneous particle-size distribution. The results of the scour analysis are presented in tables 1 and 2 and a graph of the scour depths is presented in figure 8 .

Contraction scour for the 100-year and incipient roadway-overtopping discharges was computed by use of the Laursen clear-water contraction scour equation (Richardson and others, 1995, p. 32, equation 20). At this site, the 500-year discharge resulted in unsubmerged orifice flow. Contraction scour at bridges with orifice flow is best estimated by use of the Chang pressure-flow scour equation (oral communication, J. Sterling Jones, October 4, 1996). Thus, contraction scour for this discharge was computed by use of the Chang equation (Richardson and others, 1995, p. 145-146).

Since the 500-year discharge resulted in unsubmerged orifice flow, estimates of contraction scour were also computed by use of the Laursen clear-water contraction scour equation and the Umbrell pressure-flow equation (Richardson and others, 1995, p. 144). Furthermore, contraction scour was computed by substituting estimates for the depth of flow at the downstream bridge face in the contraction scour equations. Results are provided in Appendix F.

Abutment scour was computed by use of the Froehlich equation (Richardson and others, 1995, p. 48, equation 28). Variables for the Froehlich equation include the Froude number of the flow approaching the embankments, the length of the embankment blocking flow, and the depth of flow approaching the embankment less any roadway overtopping. 


\section{Scour Results}

100-yr discharge 500-yr discharge

Contraction scour:

(Scour depths in feet)

Main channel

Live-bed scour

Clear-water scour

Depth to armoring

Left overbank

Right overbank

Local scour:

Abutment scour

10.5

12.9

11.65 .7

Left abutment

$7.5-$

$6.4-$

Right abutment

Pier scour

Pier 1

Pier 2

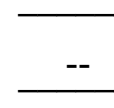

Pier 3

Abutments:

Left abutment

Right abutment

Piers:

Pier 1

Pier 2

\section{Riprap Sizing}

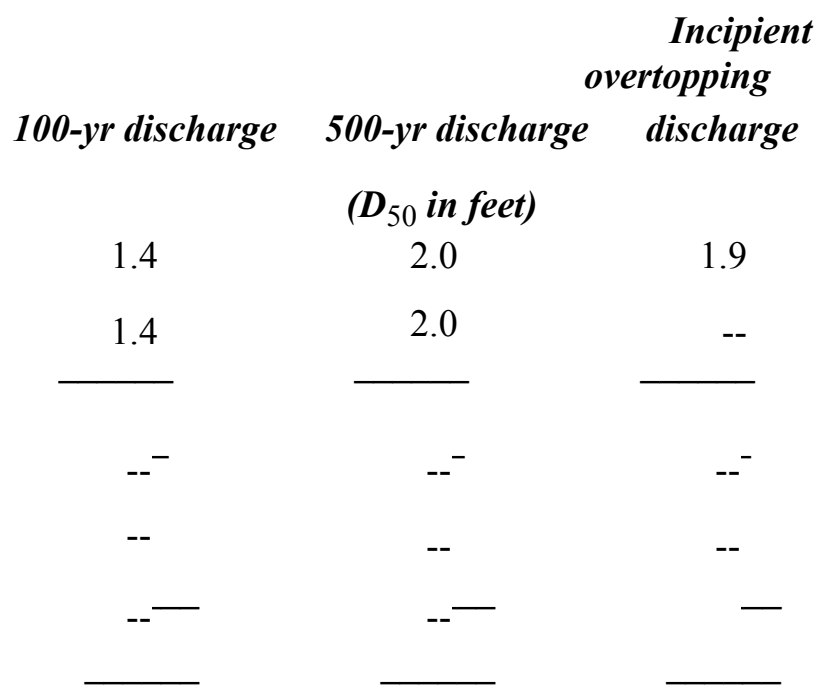




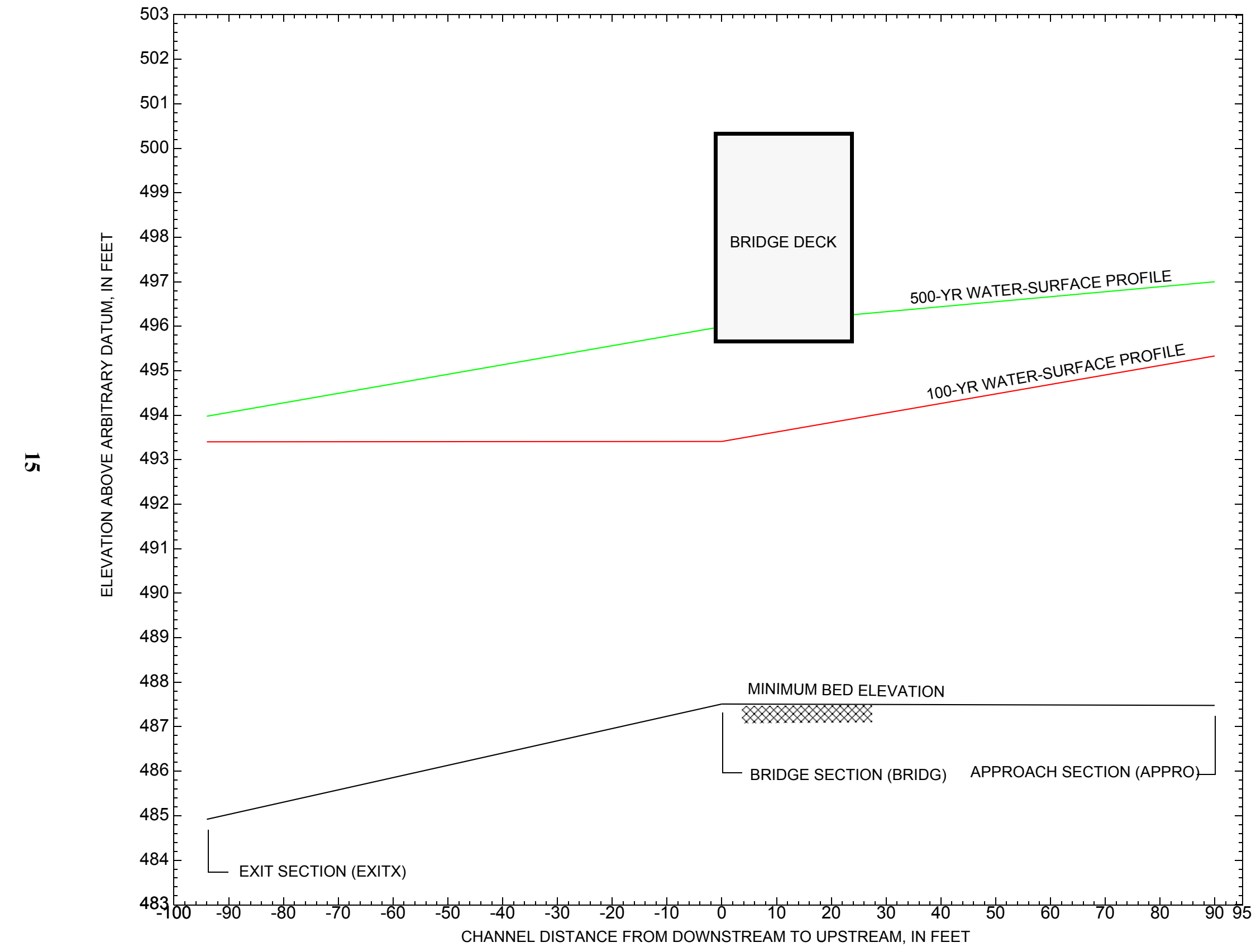

Figure 7. Water-surface profiles for the 100-year and 500-year discharges at structure WALDTH00020007 on Town Highway 2, crossing Coles Brook, Walden, Vermont. 


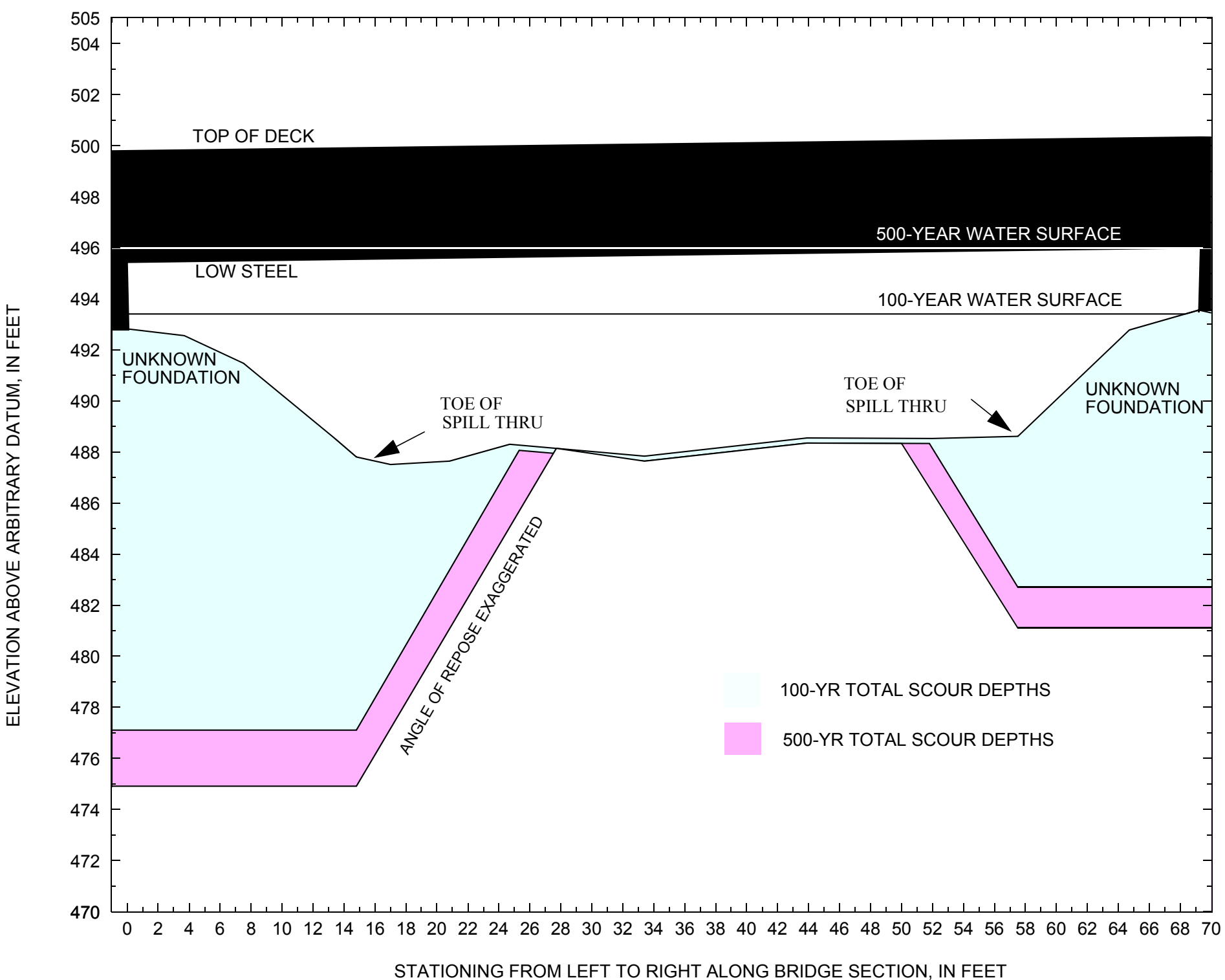

Figure 8. Scour elevations for the 100-year and 500-year discharges at structure WALDTH00020007 on Town Highway 2, crossing Coles Brook, Walden, Vermont. 


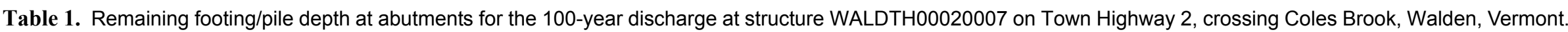
[VTAOT, Vermont Agency of Transportation; --,no data]

\begin{tabular}{|c|c|c|c|c|c|c|c|c|c|c|c|}
\hline Description & Station ${ }^{1}$ & $\begin{array}{l}\text { VTAOT } \\
\text { minimum } \\
\text { low-chord } \\
\text { elevation } \\
\text { (feet) }\end{array}$ & $\begin{array}{c}\text { Surveyed } \\
\text { minimum } \\
\text { low-chord } \\
\text { elevation } \\
\text { (feet) }\end{array}$ & $\begin{array}{c}\text { Bottom of } \\
\text { footing/pile } \\
\text { elevation }{ }^{2} \\
\text { (feet) }\end{array}$ & $\begin{array}{c}\text { Channel } \\
\text { elevation at } \\
\text { abutment/ } \\
\text { pier }^{2} \\
\text { (feet) }\end{array}$ & $\begin{array}{l}\text { Contraction } \\
\text { scour depth } \\
\text { (feet) }\end{array}$ & $\begin{array}{l}\text { Abutment } \\
\text { scour } \\
\text { depth } \\
\text { (feet) }\end{array}$ & $\begin{array}{l}\text { Pier } \\
\text { scour } \\
\text { depth } \\
\text { (feet) }\end{array}$ & $\begin{array}{l}\text { Depth of } \\
\text { total scour } \\
\text { (feet) }\end{array}$ & $\begin{array}{c}\text { Elevation of } \\
\text { scour }^{2} \\
\text { (feet) }\end{array}$ & $\begin{array}{c}\text { Remaining } \\
\text { footing/pile } \\
\text { depth } \\
\text { (feet) }\end{array}$ \\
\hline \multicolumn{12}{|c|}{100 -yr. discharge is 2,200 cubic-feet per second } \\
\hline Left abutment & 0.0 & -- & 495.4 & -- & 492.8 & -- & -- & -- & -- & -- & -- \\
\hline $\begin{array}{l}\text { Spill-through } \\
\text { toe }\end{array}$ & 14.8 & -- & -- & -- & 487.8 & 0.2 & 10.5 & -- & 10.7 & 477.1 & -- \\
\hline $\begin{array}{l}\text { Spill-through } \\
\text { toe }\end{array}$ & 57.5 & -- & -- & -- & 488.6 & 0.2 & 5.7 & -- & 5.9 & 482.7 & -- \\
\hline Right abutment & 69.3 & -- & 496.0 & -- & 493.6 & -- & -- & -- & -- & -- & -- \\
\hline
\end{tabular}

1.Measured along the face of the most constricting side of the bridge.

2.Arbitrary datum for this study.

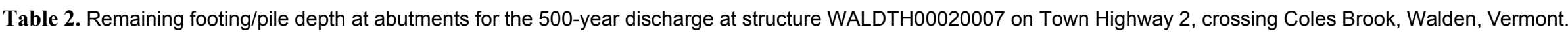
[VTAOT, Vermont Agency of Transportation; --, no data]

\begin{tabular}{|c|c|c|c|c|c|c|c|c|c|c|c|}
\hline Description & Station $^{1}$ & $\begin{array}{l}\text { VTAOT } \\
\text { minimum } \\
\text { low-chord } \\
\text { elevation } \\
\text { (feet) }\end{array}$ & $\begin{array}{l}\text { Surveyed } \\
\text { minimum } \\
\text { low-chord } \\
\text { elevation } \\
\text { (feet) }\end{array}$ & $\begin{array}{c}\text { Bottom of } \\
\text { footing/pile } \\
\text { elevation }^{2} \\
\text { (feet) }\end{array}$ & $\begin{array}{c}\text { Channel } \\
\text { elevation at } \\
\text { abutment/ } \\
\text { pier }^{2} \\
\text { (feet) }\end{array}$ & $\begin{array}{l}\text { Contraction } \\
\text { scour depth } \\
\text { (feet) }\end{array}$ & $\begin{array}{l}\text { Abutment } \\
\text { scour } \\
\text { depth } \\
\text { (feet) }\end{array}$ & $\begin{array}{l}\text { Pier } \\
\text { scour } \\
\text { depth } \\
\text { (feet) }\end{array}$ & $\begin{array}{l}\text { Depth of } \\
\text { total scour } \\
\text { (feet) }\end{array}$ & $\begin{array}{c}\text { Elevation of } \\
\text { scour }^{2} \\
\text { (feet) }\end{array}$ & $\begin{array}{c}\text { Remaining } \\
\text { footing/pile } \\
\text { depth } \\
\text { (feet) }\end{array}$ \\
\hline \multicolumn{12}{|c|}{500 -yr. discharge is 3,150 cubic-feet per second } \\
\hline Left abutment & 0.0 & -- & 495.4 & -- & 492.8 & -- & -- & -- & -- & -- & -- \\
\hline $\begin{array}{l}\text { Spill-through } \\
\text { toe }\end{array}$ & 14.8 & -- & -- & -- & 487.8 & 0.0 & 12.9 & -- & 12.9 & 474.9 & -- \\
\hline $\begin{array}{l}\text { Spill-through } \\
\text { toe }\end{array}$ & 57.5 & -- & -- & -- & 488.6 & 0.0 & 7.5 & -- & 7.5 & 481.1 & -- \\
\hline Right abutment & 69.3 & -- & 496.0 & -- & 493.6 & -- & -- & -- & -- & -- & -- \\
\hline
\end{tabular}

1.Measured along the face of the most constricting side of the bridge.

2.Arbitrary datum for this study. 


\section{SELECTED REFERENCES}

Arcement, G.J., Jr., and Schneider, V.R., 1989, Guide for selecting Manning's roughness coefficients for natural channels and flood plains: U.S. Geological Survey Water-Supply Paper 2339, 38 p.

Barnes, H.H., Jr., 1967, Roughness characteristics of natural channels: U.S. Geological Survey Water-Supply Paper 1849,213 p.

Benson, M. A., 1962, Factors Influencing the Occurrence of Floods in a Humid Region of Diverse Terrain: U.S. Geological Survey WaterSupply Paper 1580-B, 64 p.

Brown, S.A. and Clyde, E.S., 1989, Design of riprap revetment: Federal Highway Administration Hydraulic Engineering Circular No. 11, Publication FHWA-IP-89-016, 156 p.

Federal Highway Administration, 1983, Runoff estimates for small watersheds and development of sound design: Federal Highway Administration Report FHWA-RD-77-158.

Federal Highway Administration, 1993, Stream Stability and Scour at Highway Bridges: Participant Workbook: Federal Highway Administration Report FHWA-HI-91-011.

Froehlich, D.C., 1989, Local scour at bridge abutments in Ports, M.A., ed., Hydraulic Engineering--Proceedings of the 1989 National Conference on Hydraulic Engineering: New York, American Society of Civil Engineers, p. 13-18.

Hayes, D.C.,1993, Site selection and collection of bridge-scour data in Delaware, Maryland, and Virginia: U.S. Geological Survey WaterResources Investigation Report 93-4017, 23 p.

Interagency Advisory Committee on Water Data, 1982, Guidelines for determining flood flow frequency: U.S. Geological Survey, Bulletin 17B of the Hydrology Subcommittee, 190 p.

Johnson, C.G. and Tasker, G.D.,1974, Progress report on flood magnitude and frequency of Vermont streams: U.S. Geological Survey OpenFile Report 74-130, 37 p.

Lagasse, P.F., Schall, J.D., Johnson, F., Richardson, E.V., Chang, F., 1995, Stream Stability at Highway Structures: Federal Highway Administration Hydraulic Engineering Circular No. 20, Publication FHWA-IP-90-014, 144 p.

Laursen, E.M., 1960, Scour at bridge crossings: Journal of the Hydraulics Division, American Society of Civil Engineers, v. 86, no. HY2, p. 39-53.

Potter, W. D., 1957a, Peak rates of runoff in the Adirondack, White Mountains, and Maine woods area, Bureau of Public Roads

Potter, W. D., 1957b, Peak rates of runoff in the New England Hill and Lowland area, Bureau of Public Roads

Richardson, E.V. and Davis, S.R., 1995, Evaluating scour at bridges: Federal Highway Administration Hydraulic Engineering Circular No. 18, Publication FHWA-IP-90-017, 204 p.

Richardson, E.V., Simons, D.B., and Julien, P.Y., 1990, Highways in the river environment: Federal Highway Administration Publication FHWA-HI-90-016.

Ritter, D.F., 1984, Process Geomorphology: W.C. Brown Co., Debuque, Iowa, 603 p.

Shearman, J.O., 1990, User's manual for WSPRO--a computer model for water surface profile computations: Federal Highway Administration Publication FHWA-IP-89-027, 187 p.

Shearman, J.O., Kirby, W.H., Schneider, V.R., and Flippo, H.N., 1986, Bridge waterways analysis model; research report: Federal Highway Administration Publication FHWA-RD-86-108, 112 p.

Talbot, A.N., 1887, The determination of water-way for bridges and culverts.

U.S. Department of Transportation, 1993, Stream stability and scour at highway bridges, Participant Workbook: Federal Highway Administration Publication FHWA HI-91-011.

U.S. Geological Survey, 1983, St. Johnsbury, Vermont 7.5 x 15 Minute Series quadrangle map: U.S. Geological Survey Topographic Maps, Photoinspected 1983, Scale 1:25,000. 


\section{APPENDIX A: \\ WSPRO INPUT FILE}




\section{WSPRO INPUT FILE}

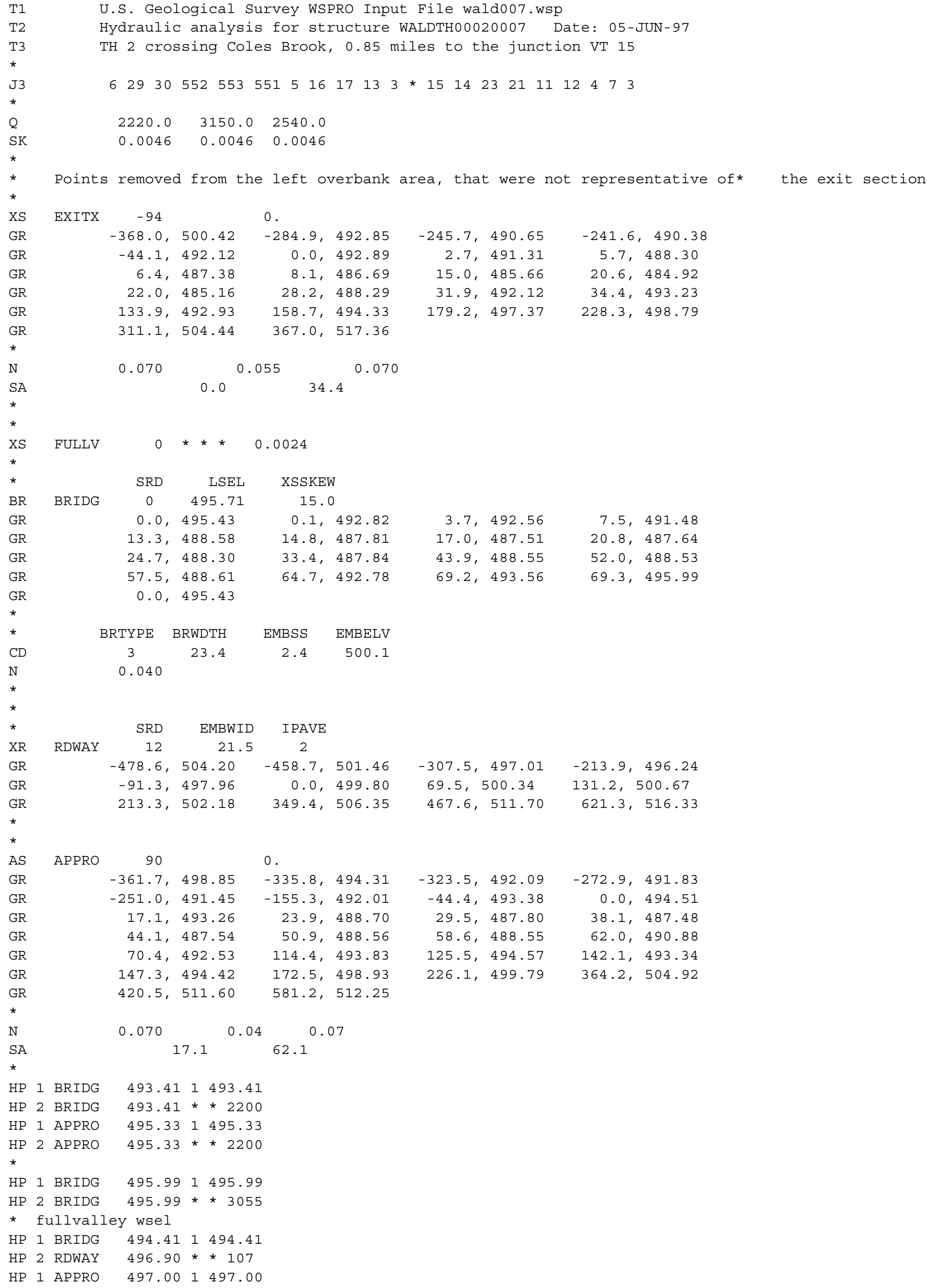




\section{APPENDIX B: \\ WSPRO OUTPUT FILE}


WSPRO OUTPUT FILE

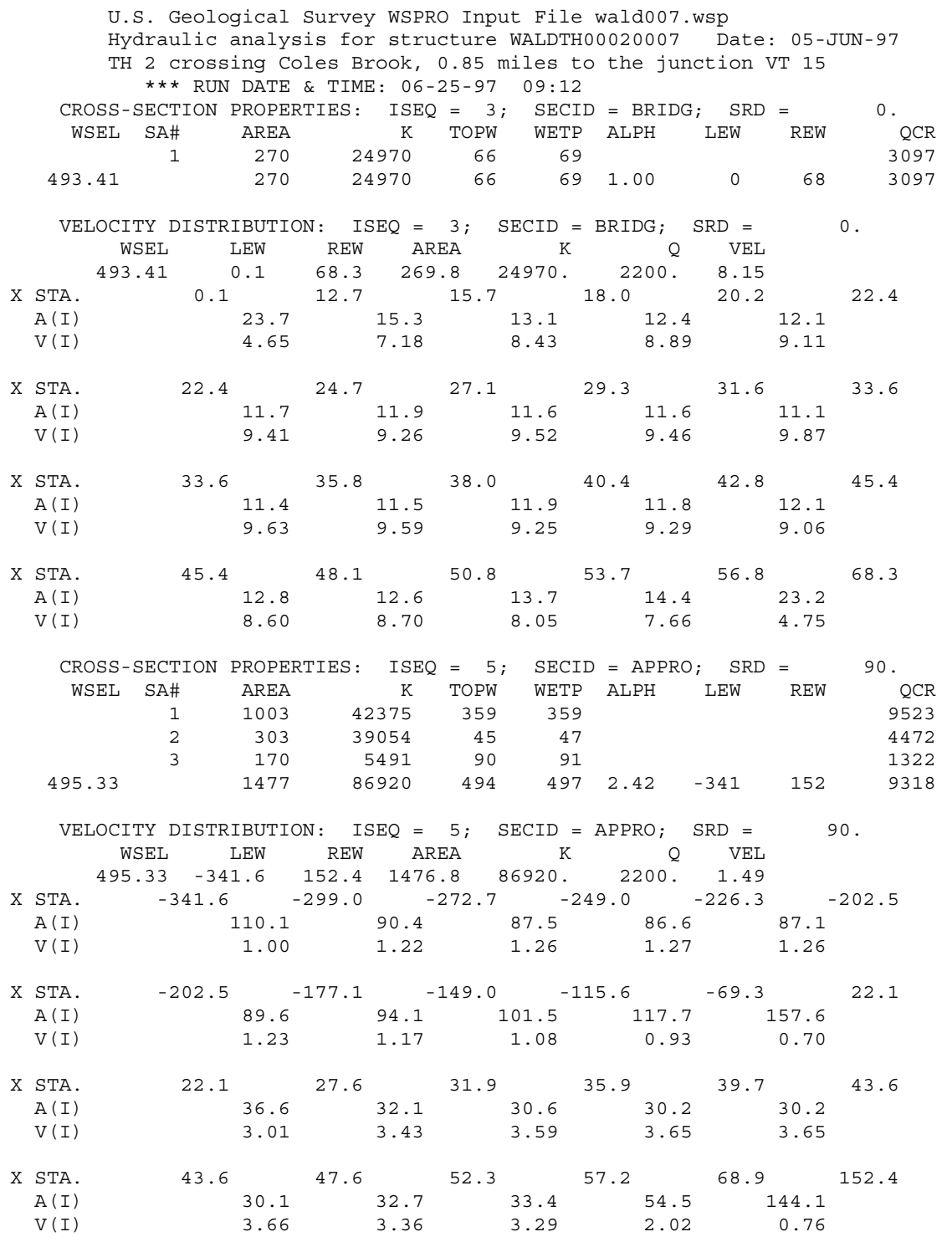




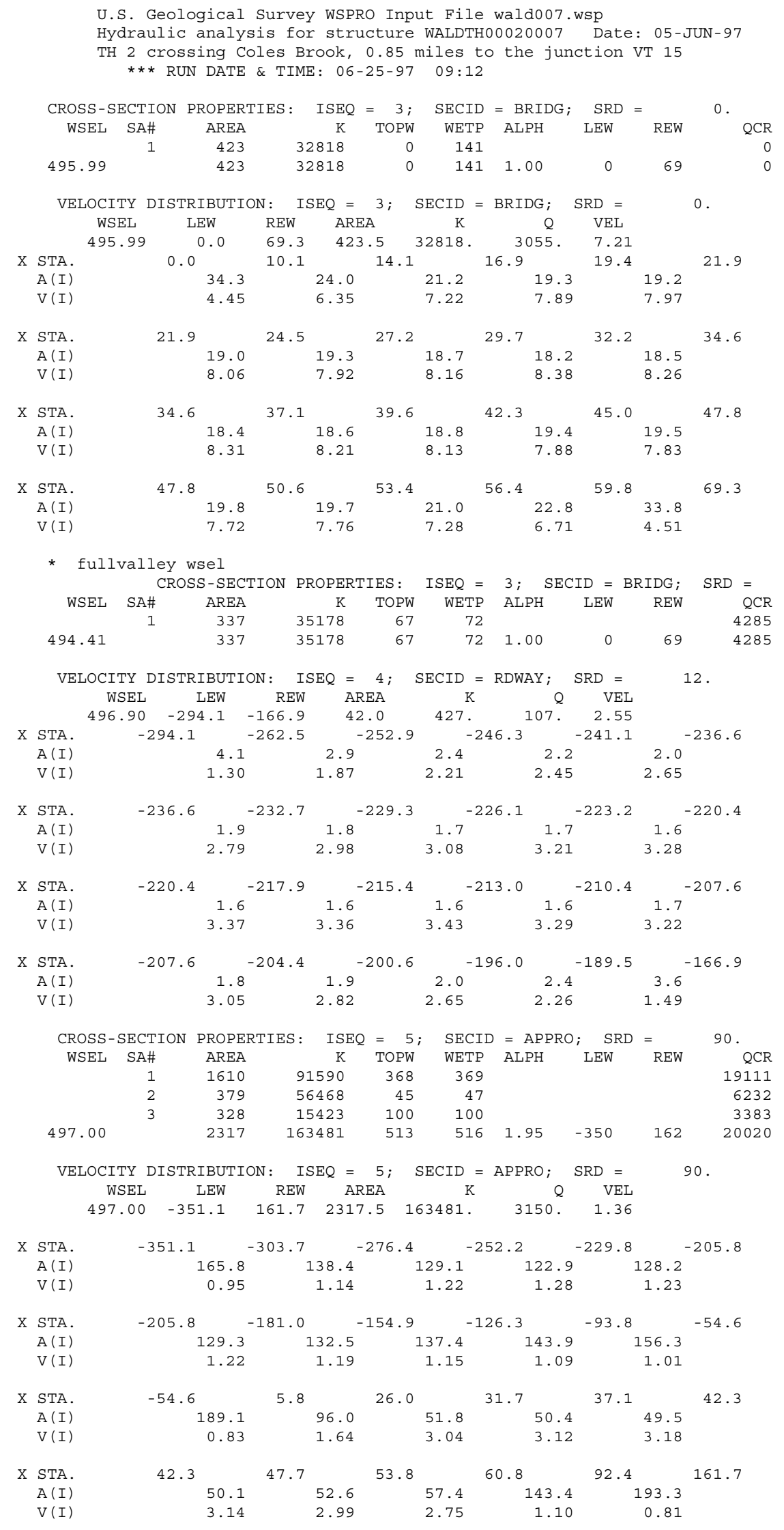


WSPRO OUTPUT FILE (continued)

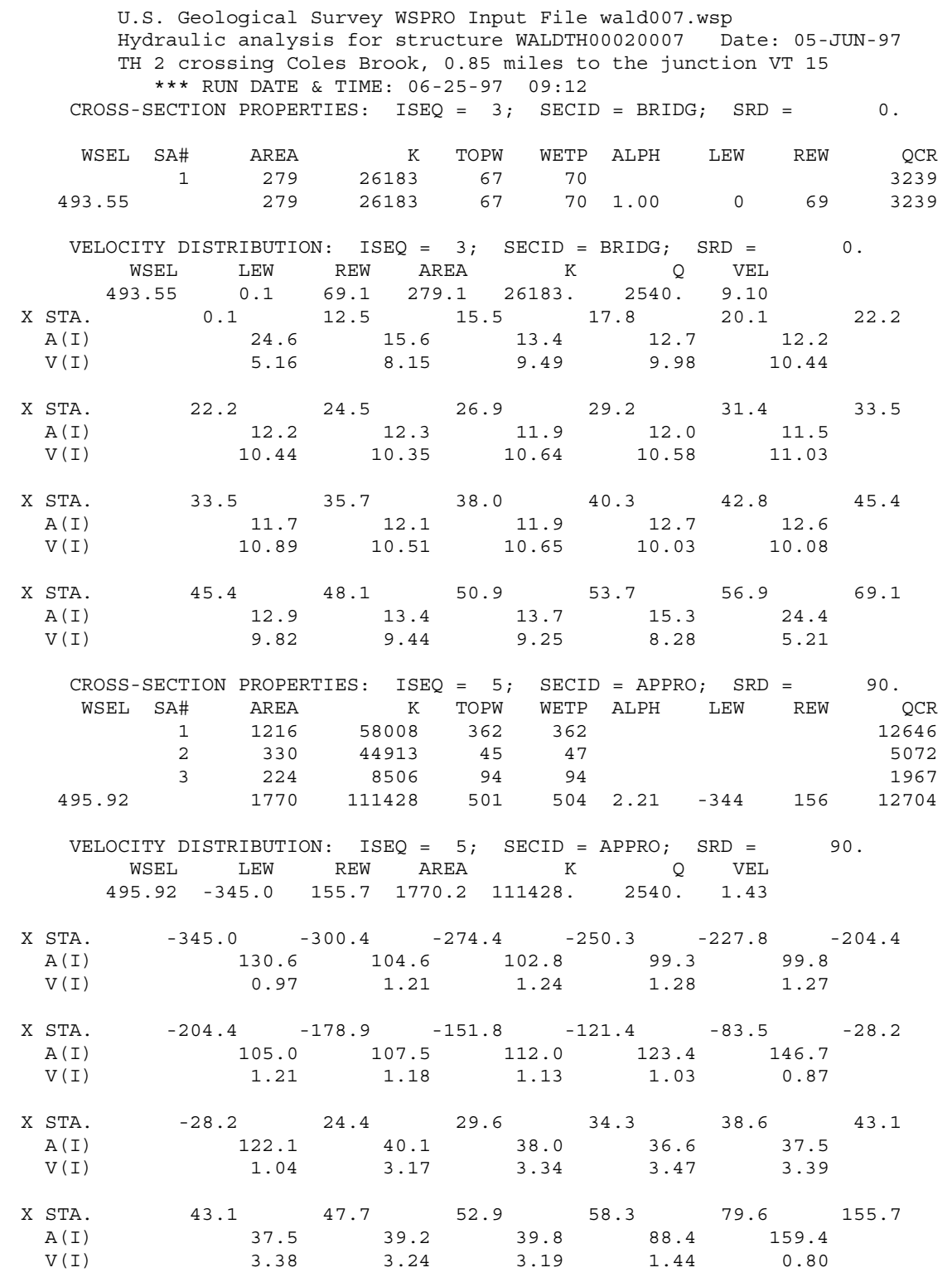


WSPRO OUTPUT FILE (continued)

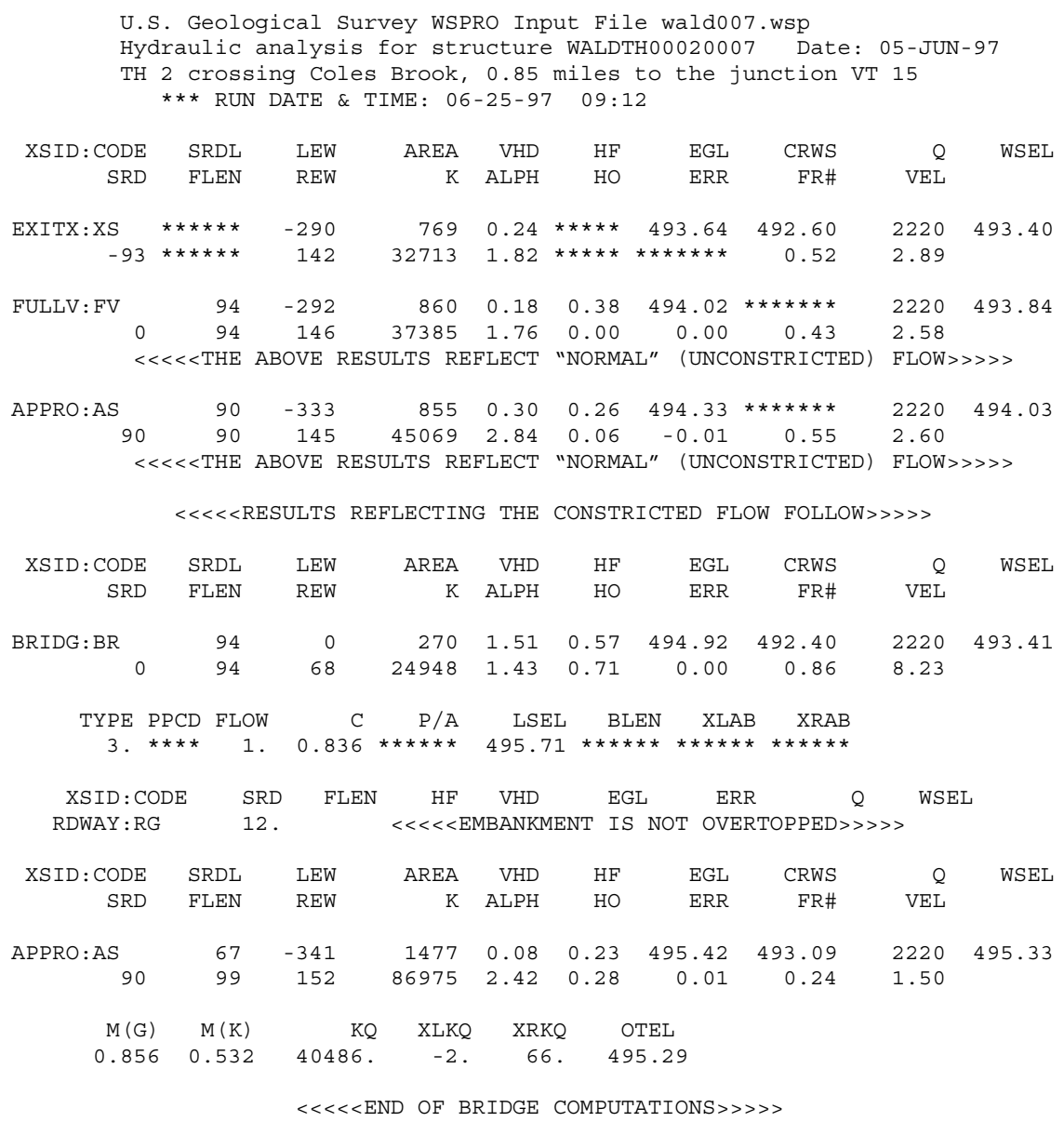

FIRST USER DEFINED TABLE.

\begin{tabular}{lrrrrrrrr} 
XSID : CODE & SRD & LEW & REW & $Q$ & K & AREA & VEL & WSEL \\
EXITX : XS & -94. & -291. & 142. & 2220. & 32713. & 769. & 2.89 & 493.40 \\
FULLV : FV & 0. & -293. & 146. & 2220. & 37385. & 860. & 2.58 & 493.84 \\
BRIDG : BR & 0. & 0. & 68. & 2220. & 24948. & 270. & 8.23 & 493.41 \\
RDWAY : RG & \multicolumn{2}{c}{$12 . * * * * * * * * * * * * *$} & $0 . * * * * * * * * * * * * * * * *$ & $2.00 * * * * * * *$ \\
APPRO : AS & 90. & -342. & 152. & 2220. & 86975. & 1477. & 1.50 & 495.33
\end{tabular}

SECOND USER DEFINED TABLE.

\begin{tabular}{|c|c|c|c|c|c|c|c|c|c|}
\hline XSID : CODE & CRWS & FR\# & YMIN & YMAX & $\mathrm{HF}$ & $\mathrm{HO}$ & VHD & EGL & WSEL \\
\hline EXT2 & 492.60 & 52 & 92 & $7.36 * *$ & $x ;$ & $\star \star *$ & 0.24 & 493.64 & 40 \\
\hline FUL & $\star * \star * * * * *$ & 43 & 5 & 7.59 & 0.38 & 0.00 & 8 & 2 & 84 \\
\hline BRIDG & 492.40 & 0.86 & 487.51 & 495.99 & 0.57 & 0.71 & 1.51 & 494.92 & 493.41 \\
\hline RWAY : RG & $\star \star \star * * \star * \star * \star * \star * *$ & $* * * *$ & 496.24 & $516.33 *$ & 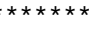 & $* *$ & $\star \star \star$ & $\star \star *$ & 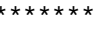 \\
\hline$A P P R O: A S$ & 493.09 & 0.24 & 487.48 & 512.25 & 0.23 & 0.28 & 0.08 & 495.42 & 495.33 \\
\hline
\end{tabular}


WSPRO OUTPUT FILE (continued)

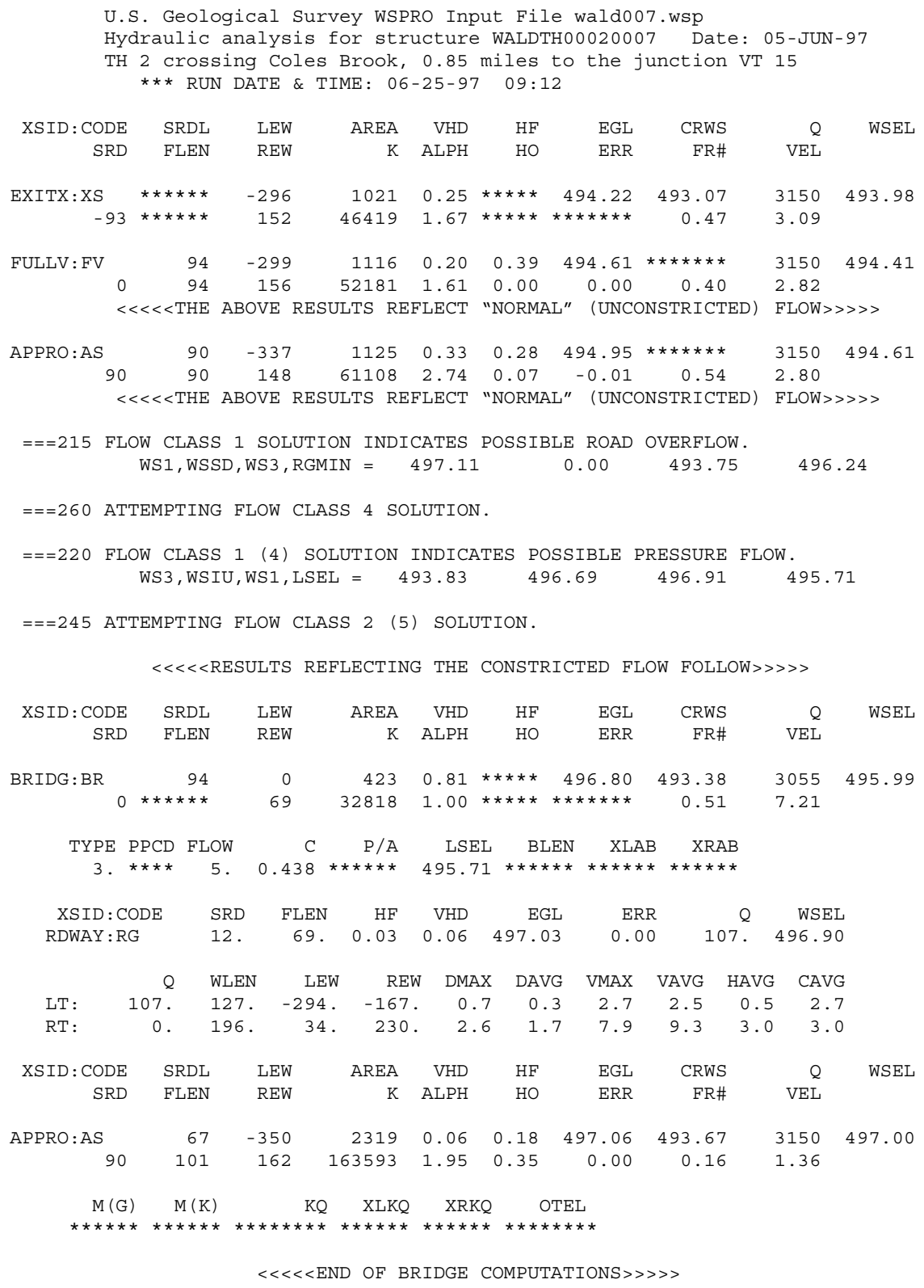

FIRST USER DEFINED TABLE.

$\begin{array}{lrrrrrrrr}\text { XSID : CODE } & \text { SRD } & \text { LEW } & \text { REW } & Q & \text { K } & \text { AREA } & \text { VEL } & \text { WSEL } \\ \text { EXITX : XS } & -94 . & -297 . & 152 . & 3150 . & 46419 . & 1021 . & 3.09 & 493.98 \\ \text { FULLV : FV } & 0 . & -300 . & 156 . & 3150 . & 52181 . & 1116 . & 2.82 & 494.41 \\ \text { BRIDG : BR } & 0 . & 0 . & 69 . & 3055 . & 32818 . & 423 . & 7.21 & 495.99 \\ \text { RDWAY : RG } & 12 . * * * * * * & 107 . & 107 . * * * * * * * * & 0 . & 2.00 & 496.90 \\ \text { APPRO : AS } & 90 . & -351 . & 162 . & 3150 . & 163593 . & 2319 . & 1.36 & 497.00\end{array}$

SECOND USER DEFINED TABLE.

$\begin{array}{lcrrrrrrrr}\text { XSID : CODE } & \text { CRWS } & \text { FR\# } & \text { YMIN } & \text { YMAX } & \text { HF } & \text { HO } & \text { VHD } & \text { EGL } & \text { WSEL } \\ \text { EXITX:XS } & 493.07 & 0.47 & 484.92 & 517.36 * * * * * * * * * * & 0.25 & 494.22 & 493.98 \\ \text { FULLV :FV } & * * * * * * * * & 0.40 & 485.15 & 517.59 & 0.39 & 0.00 & 0.20 & 494.61 & 494.41 \\ \text { BRIDG: BR } & 493.38 & 0.51 & 487.51 & 495.99 * * * * * * * * * * & 0.81 & 496.80 & 495.99 \\ \text { RDWAY:RG } & * * * * * * * * * * * * * * * & 496.24 & 516.33 & 0.03 * * * * * * & 0.06 & 497.03 & 496.90 \\ \text { APPRO:AS } & 493.67 & 0.16 & 487.48 & 512.25 & 0.18 & 0.35 & 0.06 & 497.06 & 497.00\end{array}$


WSPRO OUTPUT FILE (continued)

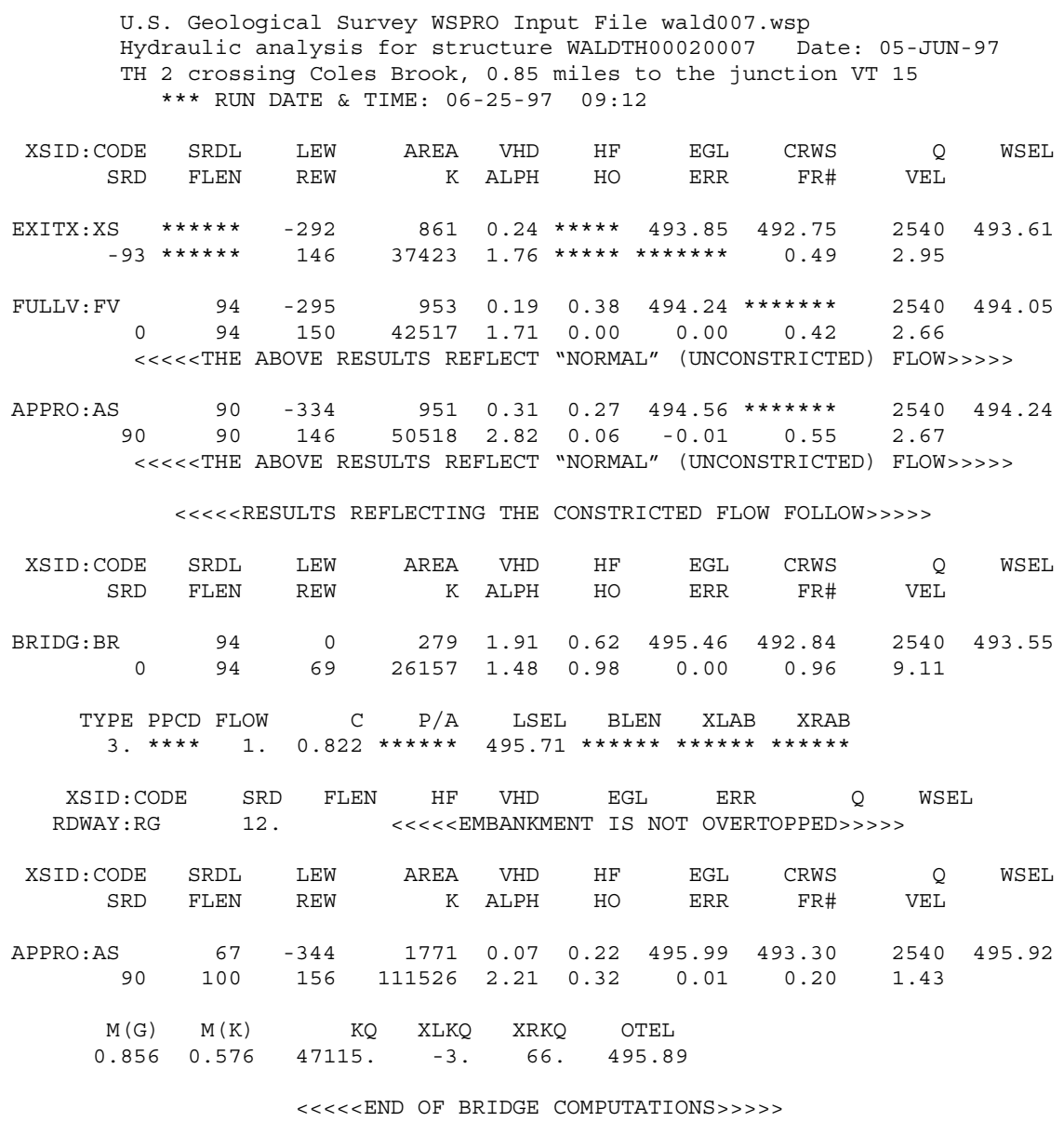

FIRST USER DEFINED TABLE.

\begin{tabular}{lrrrrrrrr} 
XSID : CODE & SRD & LEW & REW & $Q$ & K & AREA & VEL & WSEL \\
EXITX: XS & -94. & -293. & 146. & 2540. & 37423. & 861. & 2.95 & 493.61 \\
FULLV : FV & 0. & -296. & 150. & 2540. & 42517. & 953. & 2.66 & 494.05 \\
BRIDG : BR & 0. & 0. & 69. & 2540. & 26157. & 279. & 9.11 & 493.55 \\
RDWAY : RG & \multicolumn{2}{c}{$12 . * * * * * * * * * * *$} & $0 . * * * * * * * * * * * * * *$ & $2.00 * * * * * * *$ \\
APPRO: AS & 90. & -345. & 156. & 2540. & 111526. & 1771. & 1.43 & 495.92
\end{tabular}

SECOND USER DEFINED TABLE.

\begin{tabular}{|c|c|c|c|c|c|c|c|c|c|}
\hline XSID : CODE & CRWS & FR\# & YMIN & YMAX & $\mathrm{HF}$ & $\mathrm{HO}$ & VHD & EGL & WSEL \\
\hline EXITX & 492.75 & 49 & 4.92 & $7.36 * *$ & $\star \star \star * *$ & $\star * *$ & 0.24 & 493.85 & 93.61 \\
\hline EUL & $* \star * \star * \star * *$ & 4 & 5 & 7.59 & 0.38 & 0.00 & 9 & 24 & 05 \\
\hline$B R I$ & 492.84 & 0.96 & 487.51 & 495.99 & 0.62 & 0.98 & 1.91 & 495.46 & 493.55 \\
\hline RWAY : RG & 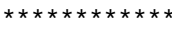 & $* * * *$ & 496.24 & $516.33 *$ & 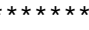 & $* *$ & $x \times x$ & $\star \star \star$ & 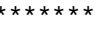 \\
\hline$A P P R O: A S$ & 493.30 & 0.20 & 487.48 & 512.25 & 0.22 & 0.32 & 0.07 & 495.99 & 495.92 \\
\hline
\end{tabular}




\section{APPENDIX C:}

\section{BED-MATERIAL PARTICLE-SIZE DISTRIBUTION}




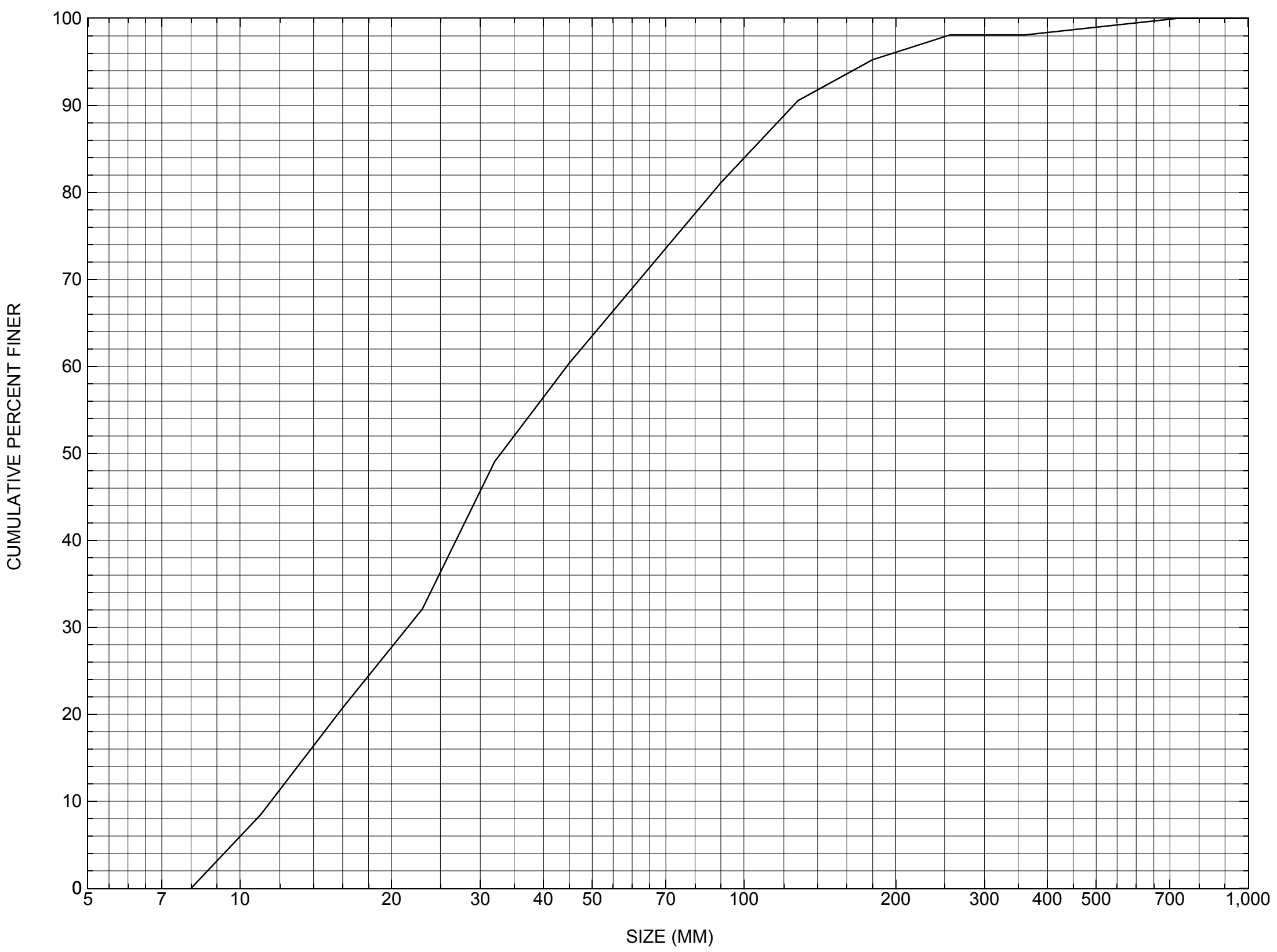

Appendix C. Bed material particle-size distribution for a pebble count in the channel approach of structure WALDTH00020007, in Weston, Vermont. 


\section{APPENDIX D: \\ HISTORICAL DATA FORM}




\section{Structure Number WALDTH00020007}

\section{General Location Descriptive}

Data collected by (First Initial, Full last name) M. IVANOFF

Date $(M M / D D / Y Y) \_\mathbf{0 4} / \underline{05} / \underline{95}$

Highway District Number (I - 2; nn) $\mathbf{0 7}$

Town (FIPS place code; I - 4; nnnnn) $\mathbf{7 5 7 0 0}$

Waterway (I - 6) COLES BROOK

Route Number TH002

Topographic Map Saint Johnsbury

Latitude (I - 16; nnnn.n) $\mathbf{4 4 2 7 6}$
County (FIPS county code; I - 3; nnn)

Mile marker (I - 11; nnn.nnn) $\mathbf{0 0 0 0 0 0}$

Road Name (I - 7): -

Vicinity (I - 9) 0.85 MI TO JCT W VT15

Hydrologic Unit Code: $\mathbf{0 1 0 8 0 1 0 2}$

Longitude (i - 17; nnnnn.n) 72133

\section{Select Federal Inventory Codes}

FHWA Structure Number (I - 8) $\mathbf{1 0 0 3 1 5 0 0 0 7 0 3 1 5}$

Maintenance responsibility $(I-21 ; n n) \_$03 $\quad$ Maximum span length $(I-48 ; n n n n) \underline{\mathbf{0 0 7 1}}$

Year built (I - 27; YYYY) 1945

Structure length (I - 49; nnnnnn) $\underline{\mathbf{0 0 0 0 7 4}}$

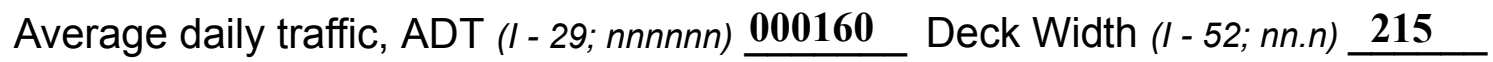

Year of ADT (I - 30; YY) $\mathbf{9 1}$

Channel \& Protection $(I-61 ; n) \underline{6}$

Opening skew to Roadway $(I-34 ; n n) \quad \mathbf{0 5}$

Waterway adequacy $(I-71 ; n)$

Operational status $(I-41 ; X)$ A

Underwater Inspection Frequency $(I-92 B ; X Y Y) \_\mathbf{N}$

Structure type (I - 43; nnn) $\mathbf{3 0 2}$

Year Reconstructed (I - 106) 1975

Approach span structure type $(I-44 ; n n n) \quad \mathbf{0 0 0}$

Clear span (nnn.n ft) _

Number of spans (I - 45; nnn) $\underline{\mathbf{0 0 1}}$

Vertical clearance from streambed (nnn.n ft) -

Number of approach spans (I - 46; nnnn) $\mathbf{0 0 0 0}$

Waterway of full opening $\left(n n n . n \mathrm{ft}^{2}\right)$

Comments:

The structural inspection report of $06 / 07 / 93$ indicates the structure is a steel stringer type bridge with a concrete deck and an asphalt road surface. There are concrete skeleton abutments. They have minor cracks and spalls reported overall. Boulder riprap has been laid on the flow through embankments in front of and around the ends of each abutment, with boulders showing in the up and downstream banks. A low, fine gravel point bar is present in the channel on the right abutment side, and presently covers two thirds of the channel. 


\section{Bridge Hydrologic Data}

Is there hydrologic data available? $\underline{\mathbf{N}}$ if No, type ctrl-n $h \quad$ VTAOT Drainage area $\left(m i^{2}\right)$ : -

Terrain character:

Stream character \& type: -

Streambed material:

Discharge Data (cfs):

$$
\begin{aligned}
& Q_{2.33}- \\
& Q_{50}-
\end{aligned}
$$

Record flood date $(M M / D D / Y Y)$ :

Estimated Discharge (cfs): Ice conditions (Heavy, Moderate, Light) : -

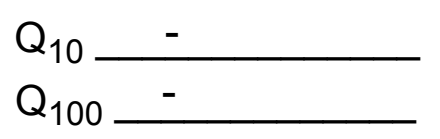

$$
\begin{aligned}
& Q_{25}- \\
& Q_{500}-
\end{aligned}
$$

Water surface elevation $(f t):-$

The stage increases to maximum highwater elevation (Rapidly, Not rapidly):

The stream response is (Flashy, Not flashy):

Describe any significant site conditions upstream or downstream that may influence the stream's stage: -

Watershed storage area (in percent): _ _ \%

The watershed storage area is: - (1-mainly at the headwaters; 2- uniformly distributed; 3-immediatly upstream oi the site)

Water Surface Elevation Estimates for Existing Structure:

\begin{tabular}{|l|l|l|l|l|l|}
\hline Peak discharge frequency & $Q_{2.33}$ & $Q_{10}$ & $Q_{25}$ & $Q_{50}$ & $Q_{100}$ \\
Water surface elevation (ft)) & - & - & - & - & - \\
Velocity (ft/sec) & - & - & - & - & - \\
\hline
\end{tabular}

Long term stream bed changes: -

Is the roadway overtopped below the $\mathrm{Q}_{100}$ ? (Yes, No, Unknown): $\mathbf{U}$ Frequency: Relief Elevation (ft): Discharge over roadway at $Q_{100}\left(f^{3} / \mathrm{sec}\right)$ :

Are there other structures nearby? (Yes, No, Unknown): $\underline{\mathbf{U}}$ Upstream distance (miles): Town: If No or Unknown, type ctrl-n os Highway No. : Structure No. : Year Built:

Clear span (ft): Clear Height $(f t)$ : Full Waterway $\left(f^{2}\right)$ : 
Downstream distance (miles): Town: Year Built:

Highway No. : Structure No. : Structure Type:

Clear span $(f t):$ Clear Height $(f t)$ : Full Waterway $\left(f^{2}\right):$

Comments:

\section{USGS Watershed Data}

Watershed Hydrographic Data

Drainage area $(D A) \underline{12.77} \mathrm{mi}^{2}$

Watershed storage (ST) $\quad \mathbf{2 . 5 4}$

Bridge site elevation $1637 \quad \mathrm{ft}$ $\%$

Main channel length

7.747 $\mathrm{mi}$

$10 \%$ channel length elevation

Lake/pond/swamp area

.325 $\mathrm{mi}^{2}$

Main channel slope (S)

(S)

83.1 $\mathrm{ft} / \mathrm{mi}$

Headwater elevation 2500 $\mathrm{ft}$

Watershed Precipitation Data

Average site precipitation in

Average headwater precipitation in

Maximum 2yr-24hr precipitation event $(124,2)$ in

Average seasonal snowfall (Sn) $\mathrm{ft}$ 


\section{Bridge Plan Data}

Are plans available? $\mathbf{N} \quad$ If no, type ctrl-n pl Date issued for construction (MM / YYYY):

Project Number

Minimum channel bed elevation:

Low superstructure elevation: USLAB DSLAB USRAB DSRAB Benchmark location description:

There is no benchmark information available.

Reference Point (MSL, Arbitrary, Other): Datum (NAD27, NAD83, Other):

Foundation Type: 4

If 1: Footing Thickness

If 2: Pile Type: (1-Wood; 2-S

(1-

(1-Spreadfooting; 2-Pile; 3- Gravity; 4-Unknown)

Footing bottom elevation:

If 3 : Footing bottom elevation:
Is boring information available?

Foundation Material Type: 3

Briefly describe material at foundation bottom elevation or around piles:

There is no foundation material information available.

Comments:

There were no bridge plans available. 


\section{Cross-sectional Data}

Is cross-sectional data available? $\underline{\mathbf{Y}}$

If no, type ctrl-n xs

Source (FEMA, VTAOT, Other)? VTAOT

This cross-section is of the upstream face. The low cord elevation is from the survey log done Comments: for this report on $08 / 09 / 95$. The low cord to bed length data is from the sketch attached to a bridge inspection report dated $06 / 07 / 93$.

\begin{tabular}{|c|c|c|c|c|c|c|c|c|c|c|c|}
\hline Station & 0.0 & 26.3 & 36.3 & 57.3 & 69.3 & - & - & - & - & - & - \\
\hline Feature & LAB & - & - & - & RAB & - & - & - & - & - & - \\
\hline $\begin{array}{l}\text { Low cord } \\
\text { elevation }\end{array}$ & 495.4 & 495.6 & 495.7 & 495.9 & 496 & - & - & - & - & - & - \\
\hline $\begin{array}{l}\text { Bed } \\
\text { elevation }\end{array}$ & 492.4 & 487.3 & 488.4 & 488.6 & 493.2 & - & - & - & - & - & - \\
\hline $\begin{array}{l}\text { Low cord to } \\
\text { bed length }\end{array}$ & 3.0 & 8.3 & 7.3 & 7.3 & 2.8 & - & - & - & - & - & - \\
\hline Station & - & - & - & - & - & - & - & - & - & - & - \\
\hline Feature & - & - & - & - & - & - & - & - & - & - & - \\
\hline $\begin{array}{l}\text { Low cord } \\
\text { elevation }\end{array}$ & - & - & - & - & - & - & - & - & - & - & - \\
\hline $\begin{array}{l}\text { Bed } \\
\text { elevation }\end{array}$ & - & - & - & - & - & - & - & - & - & - & - \\
\hline $\begin{array}{l}\text { Low cord to } \\
\text { bed length }\end{array}$ & - & - & - & - & - & - & - & - & - & - & - \\
\hline
\end{tabular}

Source (FEMA, VTAOT, Other)?

Comments:

\begin{tabular}{|l|l|l|l|l|l|l|l|l|l|l|l|l|}
\hline Station & & - & - & - & - & - & - & - & - & - \\
\hline Feature & - & - & - & - & - & - & - & - & - & - \\
\hline $\begin{array}{l}\text { Low cord } \\
\text { elevation }\end{array}$ & - & - & - & - & - & - & - & - & - & - & - \\
\hline $\begin{array}{l}\text { Bed } \\
\text { elevation }\end{array}$ & - & - & - & - & - & - & - & - & - & - \\
\hline $\begin{array}{l}\text { Low cord to } \\
\text { bed length }\end{array}$ & - & - & - & - & - & - & - & - & - & - & - \\
\hline \begin{tabular}{l} 
Station \\
\hline \begin{tabular}{l} 
Feature \\
\hline
\end{tabular}
\end{tabular}$-$ & - & - & - & - & - & - & - & - & - & - \\
\hline $\begin{array}{l}\text { Low cord } \\
\text { elevation }\end{array}$ & - & - & - & - & - & - & - & - & - & - \\
\hline $\begin{array}{l}\text { Bed } \\
\text { elevation }\end{array}$ & - & - & - & - & - & - & - & - & - & - \\
\hline $\begin{array}{l}\text { Low cord to } \\
\text { bed length }\end{array}$ & - & - & - & - & - & - & - & - & - & - \\
\hline
\end{tabular}




\section{APPENDIX E: \\ LEVEL I DATA FORM}


U. S. Geological Survey

Bridge Field Data Collection and Processing Form

Qa/Qc Check by: RB Date: $\underline{3 / 26 / 96}$

\section{Structure Number}

WALDTH00020007

Computerized by: $\mathbf{R B}$ Date: $4 / 4 / 96$

Reviewd by: LKS Date: $\underline{\mathbf{0 6} / 13 / 97}$

\section{A. General Location Descriptive}

1. Data collected by (First Initial, Full last name) L. MEDALIE

Date $(M M / D D / Y Y)$

9

/ 1995

2. Highway District Number 7

Mile marker $\mathbf{0 0 0}$

County CALENDONIA 005

Town WALDEN 75700

Waterway (I - 6) COLES BROOK

Route Number $\mathbf{T H 0 2}$

Road Name -

Hydrologic Unit Code: $\mathbf{0 1 0 8 0 1 0 2}$

3. Descriptive comments:

The bridge is located 0.85 miles from the junction of TH 2 and VT 15.

\section{B. Bridge Deck Observations}
4. Surface cover... LBUS 5
RBUS 5
LBDS 5
RBDS 5
Overall 5

(2b us, ds,lb,rb: 1- Urban; 2- Suburban; 3- Row crops; 4- Pasture; 5- Shrub- and brushland; 6- Forest; 7- Wetland)
5. Ambient water surface... US 1
UB 1
DS 1
(1- pool; 2- riffle)

6. Bridge structure type 1 (1- single span; 2- multiple span; 3- single arch; 4- multiple arch; 5-cylindrical culvert; 6- box culvert; or 7- other)
7. Bridge length $\mathbf{7 4}$
(feet)
Span length $\mathbf{7 1}$
(feet)
Bridge width 21.5 (feet)

\section{Road approach to bridge:}
8. LB 0
RB 0
( 0 even, 1- lower, 2- higher)
9. LB_2
RB $\underline{2}$
(1-Paved, 2- Not paved)

10. Embankment slope (run / rise in feet / foot)
US left
2.3:1
US right
2.6:1

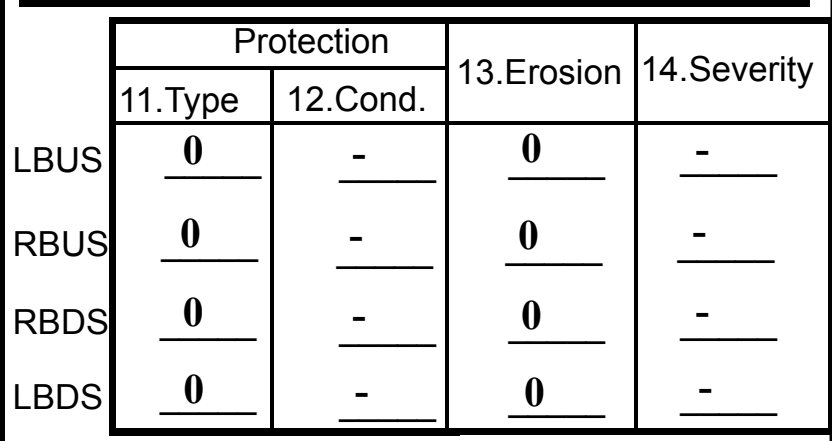

Bank protection types: 0- none; 1- $<12$ inches;

2- $<36$ inches; $3-<48$ inches;

4- $<60$ inches; 5- wall / artificial levee

Bank protection conditions: 1- good; 2- slumped;

3- eroded; 4- failed

Erosion: 0 - none; 1- channel erosion; 2 -

road wash; 3- both; 4- other

Erosion Severity: 0 - none; 1- slight; 2- moderate; 3- severe

\section{Channel approach to bridge (BF):}

15. Angle of approach: $\underline{40}$

16. Bridge skew: $\mathbf{3 5}$

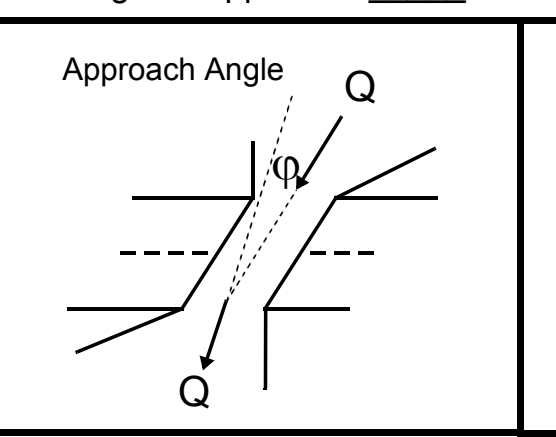
7. Channel impact zone 1:
Where? LB $(L B, R B)$
Exist? $\mathbf{Y}(Y$ or $N)$
Severity 1

Range? 9 feet US

Channel impact zone 2:

Where? $(L B, R B)$

Range? - $\quad$ feet -

(US, UB, DS) to Impact Severity: 0- none to very slight; 1- Slight; 2- Moderate; 3- Severe feet -

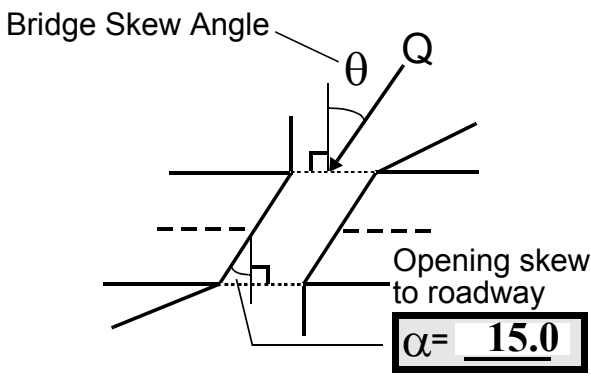

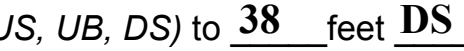

Exist? $\mathbf{N}(Y$ or $N)$

Severity - 
18. Bridge Type: $\mathbf{3}$

1a- Vertical abutments with wingwalls

1 b- Vertical abutments without wingwalls

2- Vertical abutments and wingwalls, sloping embankment Wingwalls perpendicular to abut. face

3- Spill through abutments

4- Sloping embankment, vertical wingwalls and abutments

Wingwall angle less than $90^{\circ}$.

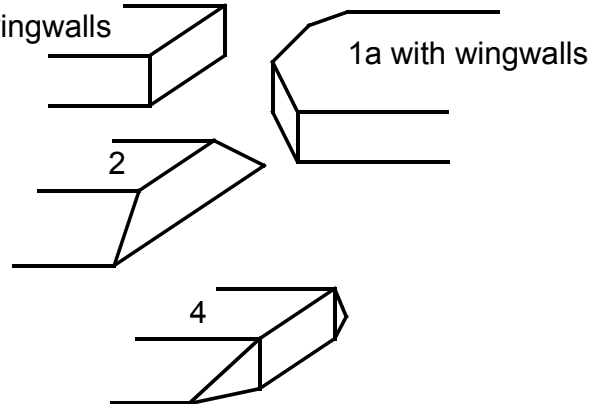

19. Bridge Deck Comments (surface cover variations, measured bridge and span lengths, bridge type variations, approach overflow width, etc.)

4. All areas have large shrubs on the banks and some spruce trees above the banks.

7. Values are from the VT AOT files. Measured bridge dimensions are the same as the historical form.

8. The left bank road approach is even for 50 feet and then it gets lower.

5. Riffles begin about 50 feet US.

18. The abutments are vertical concrete with sloping stone slabs placed below them. Wingwalls protrude as extensions from the abutment face.

\section{Upstream Channel Assessment}

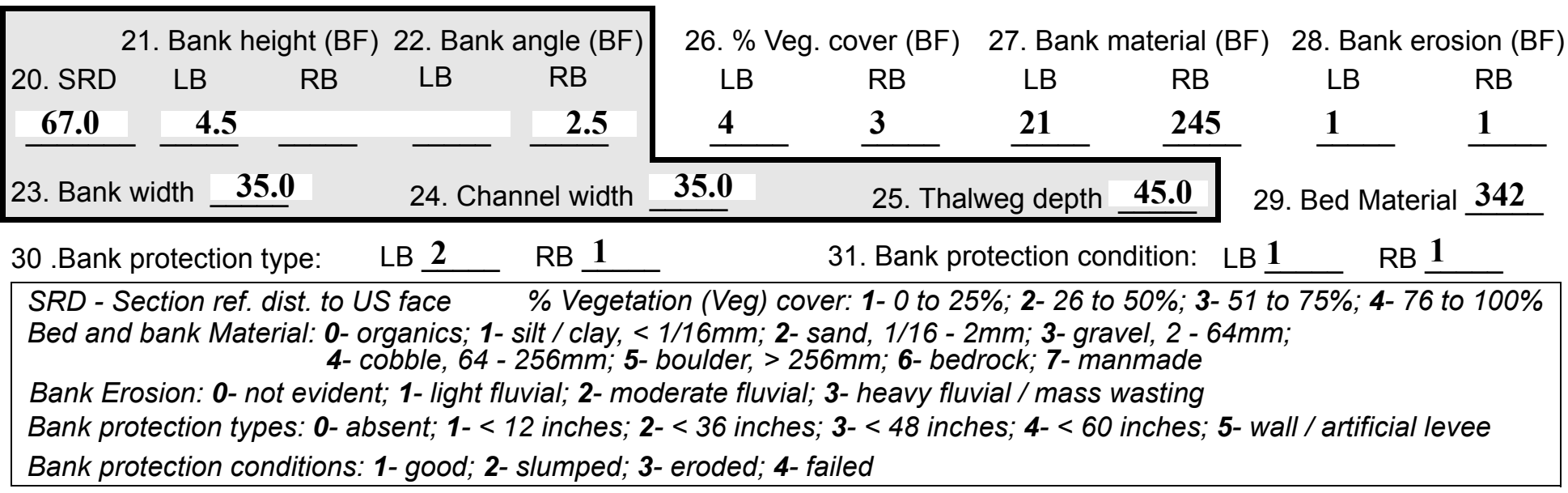

32. Comments (bank material variation, minor inflows, protection extent, etc.):

26. The percent vegetation cover for the left and right banks are based on the 10 feet tall shrubs on the banks. No trees are on the bank until 150 feet US.

29. There are occasional boulders at 74 feet US. Within 55 feet of the bridge there is only gravel and nothing larger.

30. The left bank protection is only within 10 feet of the bridge and is a continuation of the under bridge sloping stone protection. The right bank protection extends to 35 feet US. 

feet $\underline{\mathbf{D S}}$ (US, UB, DS) positioned $\mathbf{5 5}$ $\%$ LB to $\underline{\mathbf{1 0 0}} \% \mathrm{RB}$

37. Material: $\mathbf{3}$

38. Point or side bar comments (Circle Point or Side; Note additional bars, material variation, status, etc.):

The point bar material is very well sorted.

39. Is a cut-bank present? $\mathbf{Y}$ ( $Y$ or if $N$ type ctrl-n $c b)$ 40. Where? $\mathbf{L B}$ (LB or RB)

41. Mid-bank distance: $\mathbf{4 0}$ 42. Cut bank extent: 11 (US, UB) to $\underline{\mathbf{8 5}}$ feet $\underline{\mathbf{U S}}$ (US, UB, DS)

43. Bank damage: 1 (1- eroded and/or creep; 2- slip failure; 3- block failure)

44. Cut bank comments (eg. additional cut banks, protection condition, etc.):

The damage is very slight.

45. Is channel scour present? $\mathbf{N}$ ( $Y$ or if $N$ type ctrl-n $c s$ ) 46. Mid-scour distance: -

47. Scour dimensions: Length ___ Width _ _ Depth : ___ Position _-_ \% $\%$ LB to _ _ $\%$ RB

48. Scour comments (eg. additional scour areas, local scouring process, etc.):

There was no channel scour present as of $08 / 09 / 95$. The flow just US and under the bridge flows towards the left bank because of the gravel bar. Within this flow zone, the average thalweg is about 1 foot and gets as deep as 1.5 feet, but variation in the channel bottom does not justify noting channel scour.

\section{Are there major confluences? $\mathbf{N}$}

51. Confluence 1: Distance Confluence 2: Distance -
52. Enters on -

Enters on -
( $Y$ or if $N$ type ctrl-n $m c)$ (LB or $R B)$ (LB or $R B)$

54. Confluence comments (eg. confluence name):

There are no major confluences located at this site.

\section{Under Bridge Channel Assessment}

55. Channel restraint (BF)? LB 2

56. Height (BF) 57 Angle (BF)

LB $\mathrm{RB}$

LB $\mathrm{RB}$

34.5
1.0 (1- natural bank; 2- abutment; 3- artificial levee)

50. How many? -

53. Type(1-perennial; 2- ephemeral)

Type (1-perennial; 2-ephemeral)

\section{Bank width (BF) - \\ 59. Channel width $(A m b)$ \\ 63. Bed Material -}

61. Material (BF)

LB RB

$\underline{2} \quad \underline{7}$
62. Erosion (BF)

LB RB

7

Bed and bank Material: 0- organics; 1- silt / clay, < 1/16mm; 2- sand, 1/16 - 2mm; 3- gravel, 2 - 64mm; 4- cobble, 64 - 256mm; 5- boulder, > 256mm; 6- bedrock; 7- manmade

Bank Erosion: 0- not evident; 1- light fluvial; 2- moderate fluvial; 3- heavy fluvial / mass wasting

64. Comments (bank material variation, minor inflows, protection extent, etc.):

32

63. The bed material grades from sand to gravel from left to right. The material is very loose and it is easy to penetrate 1 foot.

61. The placed stone slabs that form the spill through abutments are boulder size though flat. These stones have slumped away from the vertical concrete abutment slightly and act as protection. 
65. Debris and Ice Is there debris accumulation?

(Yor $N)$ 66. Where? $\underline{Y}$

(1- Upstream; 2- At bridge; 3- Both)

67. Debris Potential $\underline{3}$

(1-Low; 2- Moderate; 3- High)

68. Capture Efficiency 1

(1-Low; 2- Moderate; 3- High)

69. Is there evidence of ice build-up? 1 (Y or $N)$

Ice Blockage Potential $\mathbf{N}$

(1-Low; 2- Moderate; 3- High)

70. Debris and Ice Comments:

1

Some logs and branches are in the stream from recent flooding, there is also some debris caught at the bridge in the I-beams. There is a debris accumulation from slip failure of the right bank at 165 feet DS.

\begin{tabular}{|l|c|c|c|c|c|c|c|c|}
\hline Abutments & $\begin{array}{c}\text { 71. Attack } \\
\angle \text { (BF) }\end{array}$ & $\begin{array}{c}72 \text {. Slope } \angle \\
\text { (Qmax) }\end{array}$ & $\begin{array}{c}\text { 73. Toe } \\
\text { loc. (BF) }\end{array}$ & $\begin{array}{c}\text { 74. Scour } \\
\text { Condition }\end{array}$ & $\begin{array}{c}75 . \text { Scour } \\
\text { depth }\end{array}$ & $\begin{array}{c}\text { 76. Exposure } \\
\text { depth }\end{array}$ & 77. Material & 78. Length \\
\hline LABUT & & $\mathbf{1 0}$ & $\mathbf{9 0}$ & $\mathbf{0}$ & $\mathbf{1}$ & - & - & $\mathbf{9 0 . 0}$ \\
\hline RABUT & $\mathbf{1}$ & $\mathbf{0}$ & $\mathbf{9 0}$ & & & $\mathbf{0}$ & $\mathbf{1}$ & $\mathbf{6 7 . 0}$ \\
\hline
\end{tabular}

Pushed: $L B$ or RB

Toe Location (Loc.): 0- even, 1- set back, 2- protrudes

Scour cond.: 0- not evident; 1- evident (comment); 2- footing exposed; 3-undermined footing; 4- piling exposed; 5- settled; 6- failed

Materials: 1- Concrete; 2- Stone masonry or drywall; 3- steel or metal; 4- wood

79. Abutment comments (eg. undermined penetration, unusual scour processes, debris, etc.):

$-$

1

The concrete abutment walls are about 3 feet high. The sloping stone slabs on the spill-through slope are at a 30 degree angle.

On the left and right abutments the bottom of the concrete is exposed up to 2 feet for a length of eight feet.

80. Wingwalls:

Exist? Material? Scour Scour Exposure $\begin{array}{ll}81 . & \\ \text { Angle? Length? }\end{array}$

USLWW: Condition? depth? depth?

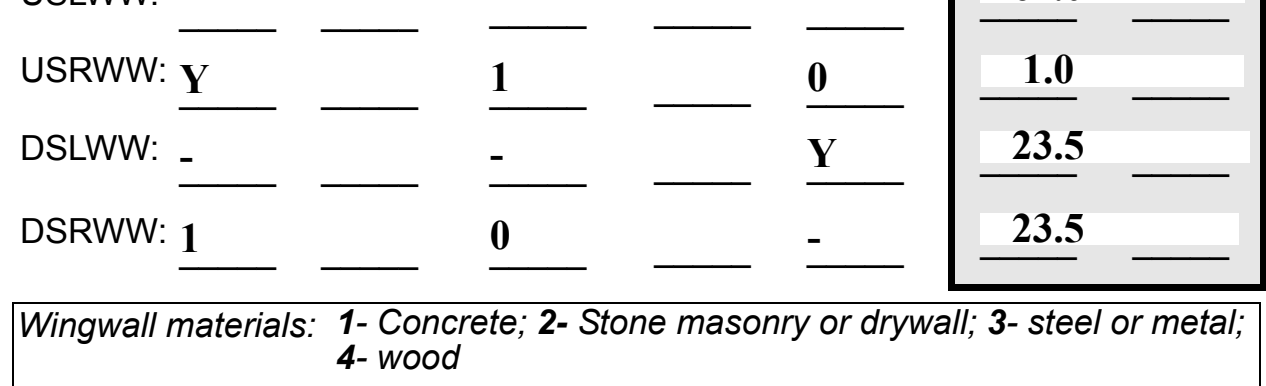

67.0

4- wood

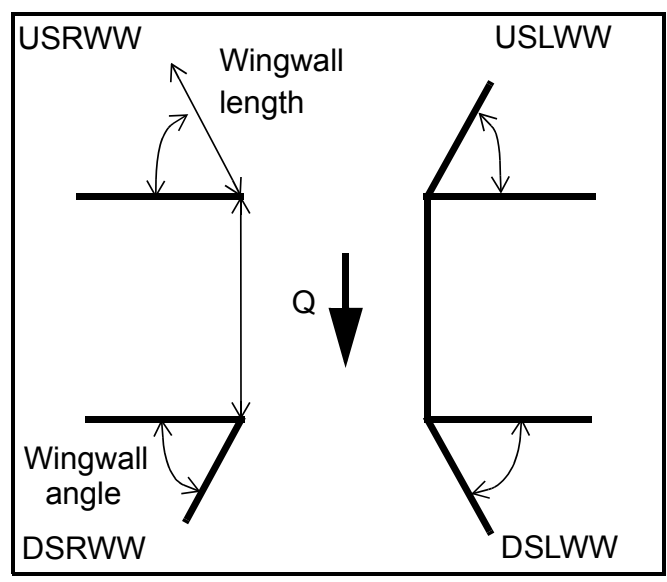

82. Bank / Bridge Protection:

\begin{tabular}{|l|l|l|l|l|l|l|l|l|}
\hline Location & USLWW & USRWW & LABUT & RABUT & LB & RB & DSLWW & DSRWW \\
\hline Type & - & $\mathbf{0}$ & $\mathbf{Y}$ & - & - & $\mathbf{1}$ & $\mathbf{1}$ & $\mathbf{1}$ \\
\hline Condition & $\mathbf{Y}$ & - & $\mathbf{1}$ & - & - & $\mathbf{2}$ & $\mathbf{1}$ & $\mathbf{1}$ \\
\hline Extent & $\mathbf{1}$ & - & $\mathbf{0}$ & $\mathbf{0}$ & $\mathbf{2}$ & $\mathbf{2}$ & $\mathbf{2}$ & - \\
\hline
\end{tabular}

Bank / Bridge protection types: 0- absent; 1- < 12 inches; 2- < 36 inches; 3- < 48 inches; 4- < 60 inches; 
83. Wingwall and protection comments (eg. undermined penetration, unusual scour processes, etc.):

-
-
-
-
-
1
1
3
1
1
3

\section{Piers:}

84. Are there piers? Th (Y or if $N$ type ctrl-n pr)

\begin{tabular}{|l|l|l|l|l|l|l|l|}
\hline \multirow{2}{*}{$\begin{array}{l}85 . \\
\text { Pier no. }\end{array}$} & \multicolumn{3}{|c|}{ width (w) feet } & \multicolumn{3}{c|}{ elevation (e) feet } \\
\cline { 2 - 9 } & w1 & w2 & w3 & e@w1 & e@w2 & e@w3 \\
\hline Pier 1 & - & - & - & - & - & - \\
\hline Pier 2 & - & - & - & - & - & - \\
\hline Pier 3 & - & - & - & - & - & - \\
\hline Pier 4 & - & - & - & - & - & - \\
\hline
\end{tabular}

\begin{tabular}{|l|l|l|l|l|}
\hline Level 1 Pier Descr. & \multicolumn{1}{|c|}{1} & \multicolumn{1}{|c|}{2} & \multicolumn{1}{|c|}{3} & \multicolumn{1}{|c|}{} \\
\hline 86. Location (BF) & e slop- & . The & d stone & N \\
\hline 87. Type & ing & abut & slabs & - \\
\hline 88. Material & ends & ment & - & - \\
\hline 89. Shape & of & pro- & & - \\
\hline 90. Inclined? & the & tec- & & - \\
\hline 91. Attack $\angle$ (BF) & abut & tion & & - \\
\hline 92. Pushed & ment & refer & & - \\
\hline 93. Length (feet) & - & - & - & - \\
\hline 94. \# of piles & walls & red & & - \\
\hline 95. Cross-members & act & to & & - \\
\hline 96. Scour Condition & as & are & & - \\
\hline 97. Scour depth & wing & the & & - \\
\hline 98. Exposure depth & walls & place & & - \\
\hline
\end{tabular}

LFP, LTB, LB, MCL, MCM, MCR, RB, RTB, RFP

1- Solid pier, 2- column, 3- bent

1-Wood; 2- concrete; 3- metal; 4- stone

1- Round; 2- Square; 3- Pointed

Y-yes; $N-$ no

$L B$ or $R B$

0- none; 1- laterals; 2- diagonals; 3- both

0- not evident; 1- evident (comment);

2- footing exposed; 3- piling exposed;

4- undermined footing; 5- settled; 6- failed 
99. Pier comments (eg. undermined penetration, protection and protection extent, unusual scour processes, etc.):

-
-
-
-
-
-
-
-
-

100.

\section{E. Downstream Channel Assessment}

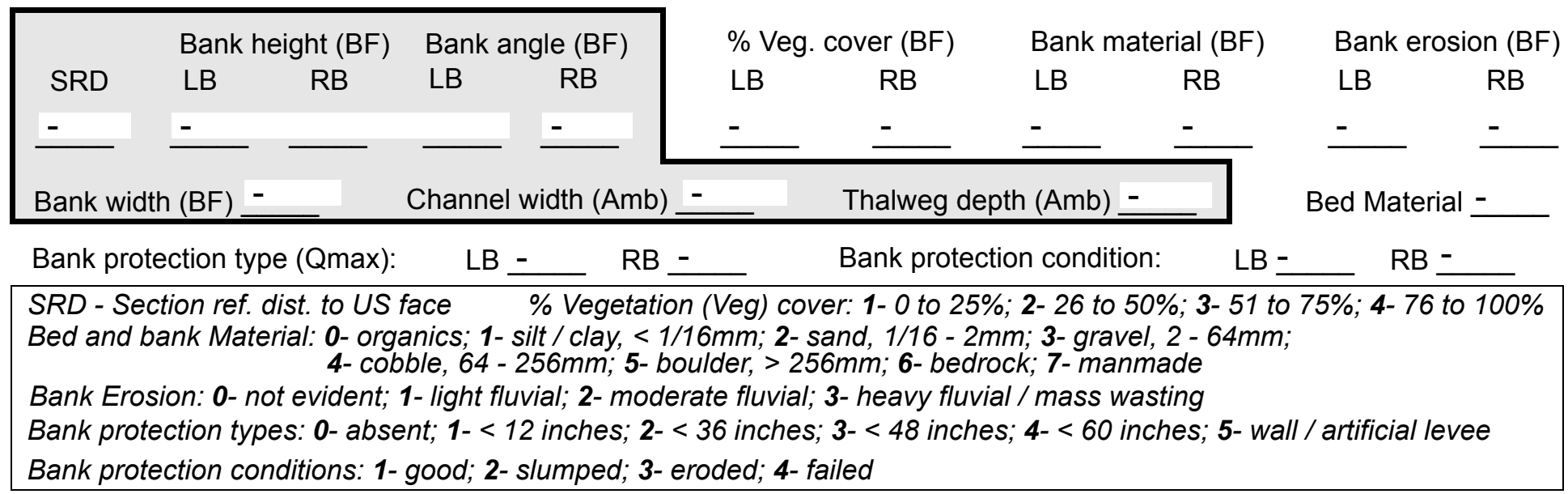

Comments (eg. bank material variation, minor inflows, protection extent, etc.):

-
-
-
-
-
-
-
-
-
-
-
-
-
-
-

101. Is a drop structure present? _ ( $Y$ or $N$, if $N$ type ctrl-n ds) 102. Distance: ___ feet

103. Drop: -_ feet 104. Structure material: Th (1- steel sheet pile; 2- wood pile; 3- concrete; 4- other) 105. Drop structure comments (eg. downstream scour depth):

ere are no piers at this site. 
106. Point/Side bar present? (Y or $N$. if $N$ type ctrl-n pb)Mid-bar distance:

Mid-bar width:

Point bar extent: feet 4

(US, UB, DS) to 3 feet $\underline{2}$ (US, UB,

$B, D S)$ positioned 2 $\%$ LB to $\underline{\mathbf{2}} \%$ RB

Material: 2

Point or side bar comments (Circle Point or Side; note additional bars, material variation, status, etc.):

\section{4}

2

2

1

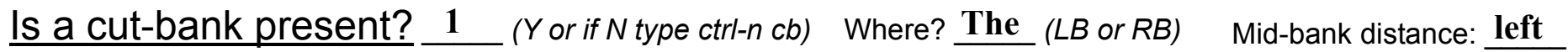

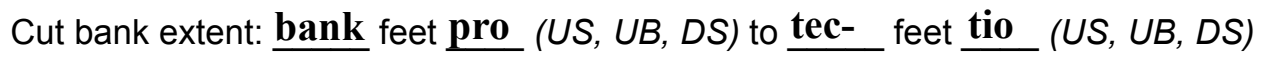

Bank damage: $\underline{\mathbf{n}}$ (1- eroded and/or creep; 2- slip failure; 3- block failure)

Cut bank comments (eg. additional cut banks, protection condition, etc.):

extends DS 55 feet. The right bank protection extends from 60 feet to 118 feet DS. Moderate fluvial erosion on the left bank begins at the end of the protected area.

Is channel scour present? ( $Y$ or if $N$ type ctrl-n cs)

Mid-scour distance:

Scour dimensions: Length Width Depth:

Positioned $\%$ LB to $\%$ RB

Scour comments (eg. additional scour areas, local scouring process, etc.):

Are there major confluences? $\mathbf{N}$ ( $Y$ or if $N$ type ctrl-n $m c)$ Confluence 1: Distance Ther Confluence 2: Distance no Enters on $\mathbf{e}$ (LB or $R B)$ Confluence comments (eg. confluence name):

structures present at this site.

\section{F. Geomorphic Channel Assessment}

107. Stage of reach evolution

1- Constructed

2- Stable

3- Aggraded

4- Degraded

5- Laterally unstable

6- Vertically and laterally unstable 
108. Evolution comments (Channel evolution not considering bridge effects; See HEC-20, Figure 1 for geomorphic descriptors):
Y
170
10
130
DS
185
DS
10
25
23 


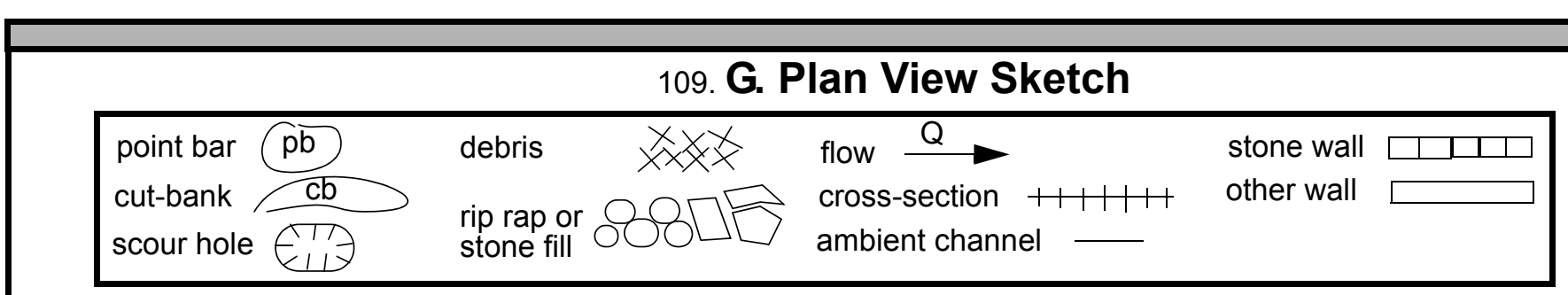


APPENDIX F:

SCOUR COMPUTATIONS 
SCOUR COMPUTATIONS

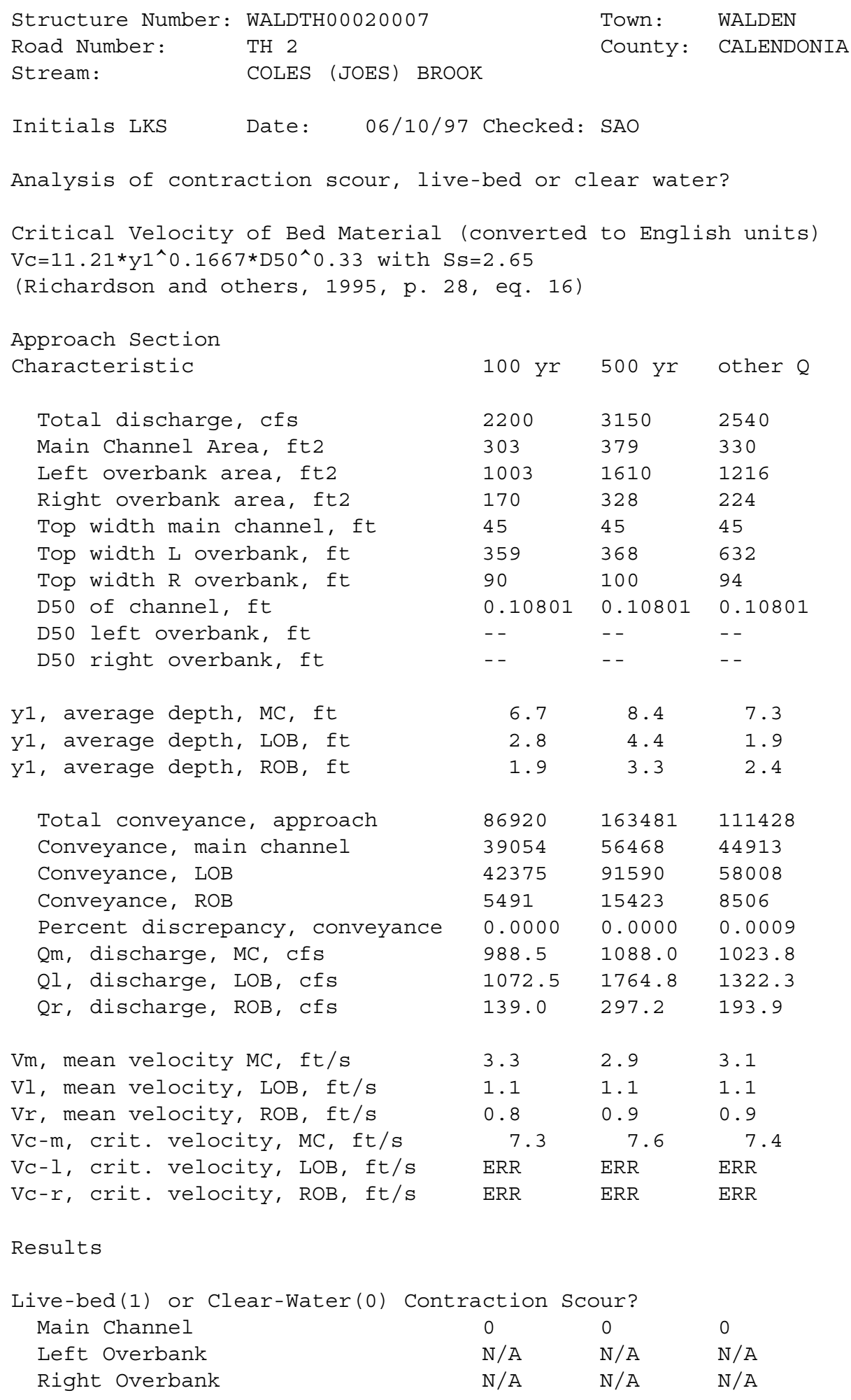


Clear water Contraction Scour in MAIN CHANNEL

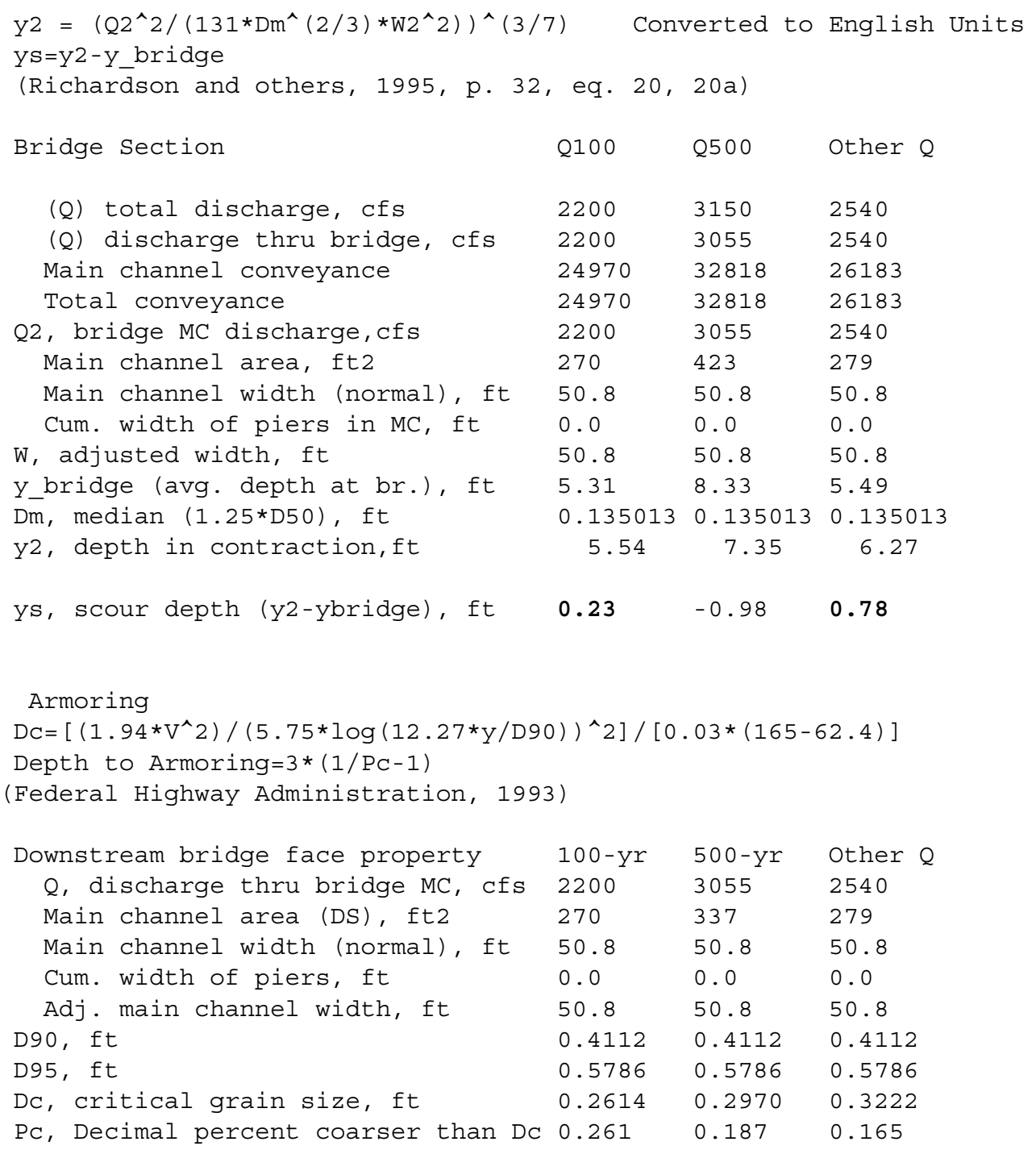




\begin{tabular}{|c|c|c|c|c|}
\hline \multicolumn{5}{|c|}{$\begin{array}{l}\text { Umbrell pressure flow equation } \\
(\mathrm{Hb}+\mathrm{Ys}) / \mathrm{ya}=1.1021 *[(1-\mathrm{w} / \mathrm{ya}) *(\mathrm{Va} / \mathrm{Vc})]^{\wedge} 0.6031 \\
\text { (Richardson and other, 1995, p. 144-146) }\end{array}$} \\
\hline & Q100 & Q500 & OtherQ & \\
\hline Q, total, cfs & 2200 & 3150 & 2540 & \\
\hline Q, thru bridge $\mathrm{MC}$, cfs & 2200 & 3055 & 2540 & \\
\hline Vc, critical velocity, ft/s & 7.34 & 7.61 & 7.44 & \\
\hline Va, velocity MC approach, ft/s & 3.26 & 2.87 & 3.10 & \\
\hline Main channel width (normal), ft & 50.8 & 50.8 & 50.8 & \\
\hline Cum. width of piers in MC, ft & 0.0 & 0.0 & 0.0 & \\
\hline W, adjusted width, ft & 50.8 & 50.8 & 50.8 & \\
\hline qbr, unit discharge, ft2/s & 43.3 & 60.1 & 50.0 & \\
\hline Area of full opening, ft2 & 270.0 & 423.0 & 279.0 & \\
\hline $\mathrm{Hb}$, depth of full opening, ft & 5.31 & 8.33 & 5.49 & \\
\hline Fr, Froude number, bridge MC & 0 & 0.51 & 0 & \\
\hline Cf, Fr correction factor $(<=1.0)$ & 0.00 & 1.00 & 0.00 & \\
\hline **Area at downstream face, ft2 & $\mathrm{N} / \mathrm{A}$ & 337 & $\mathrm{~N} / \mathrm{A}$ & \\
\hline$* * \mathrm{Hb}$, depth at downstream face, ft & $\mathrm{N} / \mathrm{A}$ & 6.63 & $\mathrm{~N} / \mathrm{A}$ & \\
\hline$\star *$ Fr, Froude number at DS face & ERR & 0.62 & ERR & \\
\hline$* * C f$, for downstream face $(<=1.0)$ & $\mathrm{N} / \mathrm{A}$ & 1.00 & $\mathrm{~N} / \mathrm{A}$ & \\
\hline Elevation of Low steel, ft & 0 & 495.71 & 0 & \\
\hline Elevation of Bed, ft & -5.31 & 487.38 & -5.49 & \\
\hline Elevation of Approach, ft & 0 & 497 & 0 & \\
\hline Friction loss, approach, ft & 0 & 0.18 & 0 & \\
\hline Elevation of WS immediately US, ft & 0.00 & 496.82 & 0.00 & \\
\hline ya, depth immediately US, ft & 5.31 & 9.44 & 5.49 & \\
\hline Mean elevation of deck, ft & 0 & 500.07 & 0 & \\
\hline$w$, depth of overflow, ft $(>=0)$ & 0.00 & 0.00 & 0.00 & \\
\hline Cc, vert contrac correction $(<=1.0)$ & 1.00 & 0.97 & 1.00 & \\
\hline$* * C c$, for downstream face $(<=1.0)$ & $\mathrm{ERR}$ & 0.909574 & $\mathrm{ERR}$ & \\
\hline Ys, scour w/Chang equation, ft & $\mathrm{N} / \mathrm{A}$ & -0.18 & $\mathrm{~N} / \mathrm{A}$ & \\
\hline Ys, scour w/Umbrell equation, ft & $\mathrm{N} / \mathrm{A}$ & -2.55 & $\mathrm{~N} / \mathrm{A}$ & \\
\hline
\end{tabular}




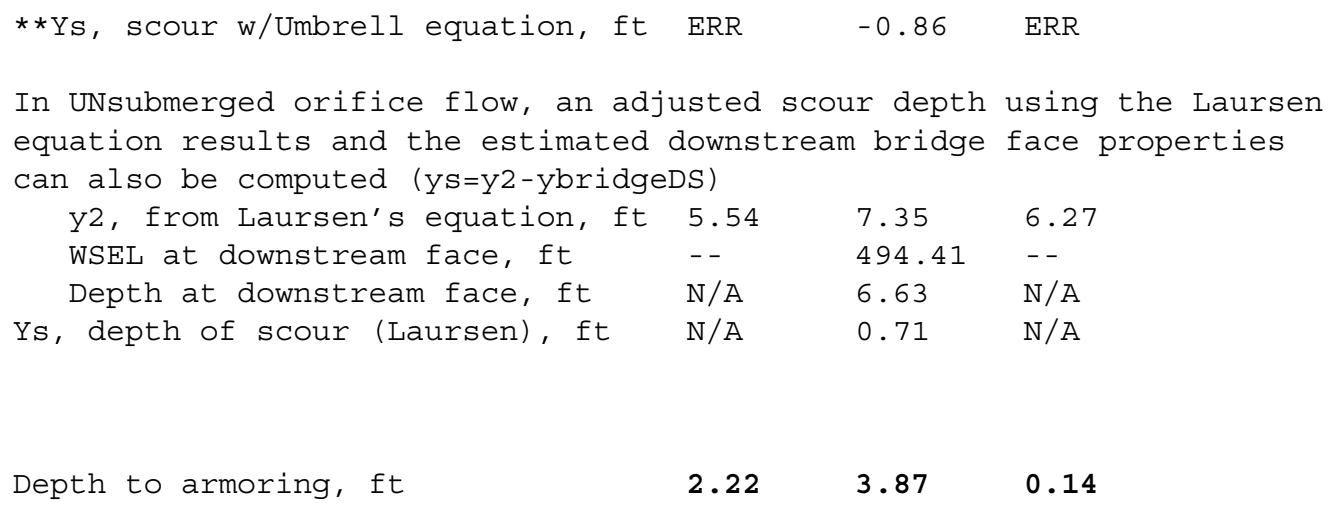

Abutment Scour

Froehlich's Abutment Scour

$\mathrm{Ys} / \mathrm{Y} 1=2.27 * \mathrm{~K} 1 * \mathrm{~K} 2 *\left(\mathrm{a}^{\prime} / \mathrm{Y} 1\right)^{\wedge} 0.43 * \mathrm{Fr} 1^{\wedge} 0.61+1$

(Richardson and others, 1995, p. 48, eq. 28)

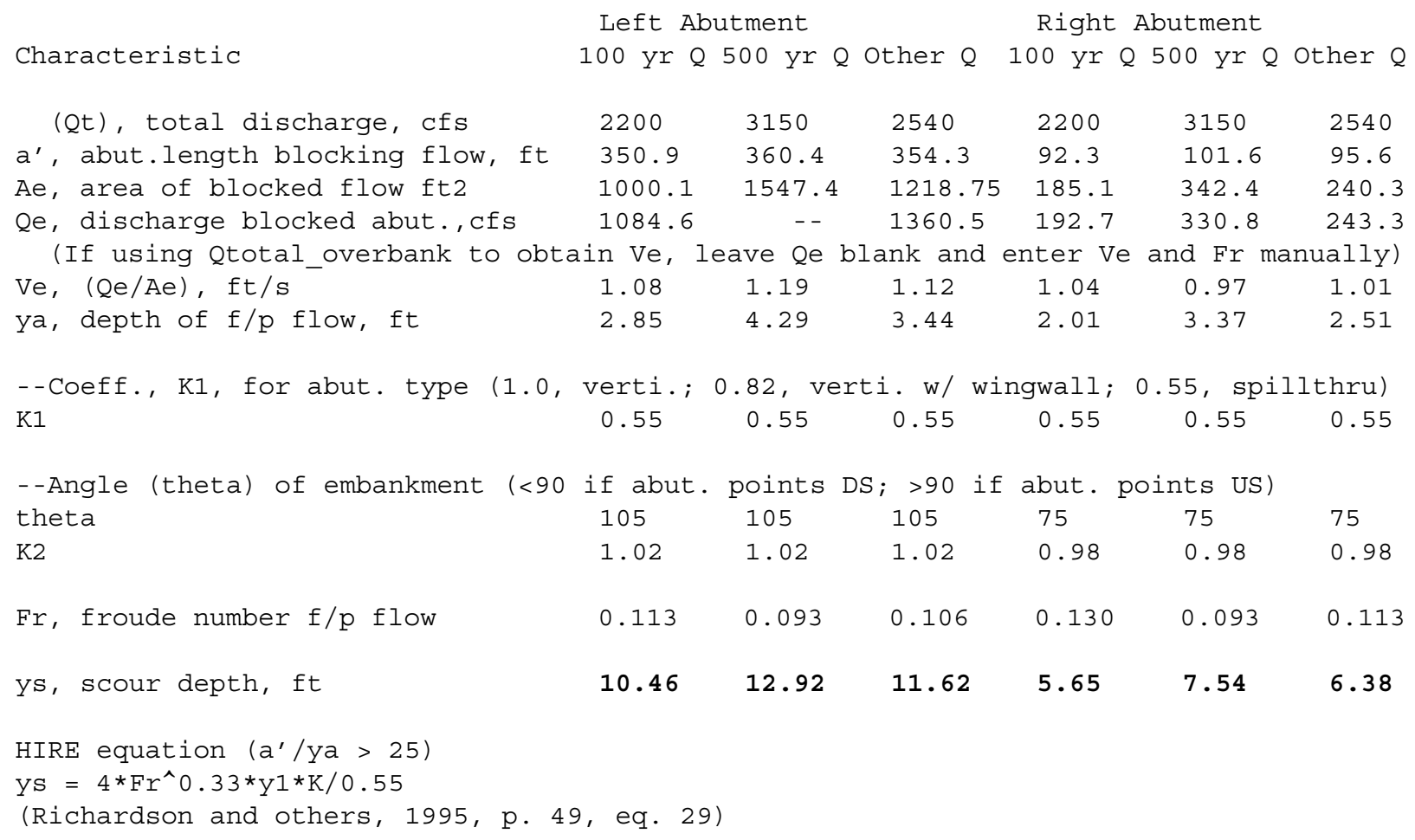




\begin{tabular}{|c|c|c|c|c|c|c|}
\hline a' (abut length blocked, ft) & 350.9 & 360.4 & 354.3 & 92.3 & 101.6 & 95.6 \\
\hline y1 (depth f/p flow, ft) & 2.85 & 4.29 & 3.44 & 2.01 & 3.37 & 2.51 \\
\hline$a^{\prime} / y^{1}$ & 123.12 & 83.94 & 103.00 & 46.03 & 30.15 & 38.03 \\
\hline Skew correction (p. 49, fig. 16) & 1.03 & 1.03 & 1.03 & 0.95 & 0.95 & 0.95 \\
\hline Froude no. f/p flow & 0.11 & 0.09 & 0.11 & 0.13 & 0.09 & 0.11 \\
\hline $\begin{array}{c}\text { Ys w/ corr. factor K1/0.55: } \\
\text { vertical }\end{array}$ & 10.43 & 14.73 & 12.32 & 7.06 & 10.62 & 8.45 \\
\hline vertical w/ ww's & 8.56 & 12.08 & 10.11 & 5.79 & 8.71 & 6.93 \\
\hline spill-through & 5.74 & 8.10 & 6.78 & 3.88 & 5.84 & 4.65 \\
\hline Abutment riprap Sizing & & & & & & \\
\hline \multirow{2}{*}{\multicolumn{7}{|c|}{$\begin{array}{l}\text { Isbash Relationship } \\
\text { D50=Y* } \mathrm{K}^{\star} \mathrm{Fr} 2 /(\mathrm{Ss}-1) \text { and } \mathrm{D} 50=\mathrm{Y}^{\star} \mathrm{K} *\left(\mathrm{Fr} r^{\wedge} 2\right)^{\wedge} 0.14 /(\mathrm{Ss}-1) \\
\text { (Richardson and others, 1995, p112, eq. 81,82) }\end{array}$}} \\
\hline & & & & & & \\
\hline Downstream bridge face property & Q100 & Q500 & Other $Q$ & Q100 & Q500 & Other $Q$ \\
\hline Fr, Froude Number & 0.86 & 0.62 & 0.96 & 0.87 & 0.62 & 0.96 \\
\hline y, depth of flow in bridge, ft & 5.31 & 6.63 & 5.49 & 5.31 & 6.63 & 5.49 \\
\hline Median stone Diameter for riprap & : left & utment & & right & abutment, & ft \\
\hline Fr<=0.8 (vertical abut.) & $\mathrm{ERR}$ & 1.58 & ERR & ERR & 1.58 & ERR \\
\hline Fr>0.8 (vertical abut.) & 2.13 & ERR & 2.27 & 2.14 & ERR & 2.27 \\
\hline Fr<=0.8 (spillthrough abut.) & $\mathrm{ERR}$ & 1.37 & ERR & ERR & 1.37 & ERR \\
\hline Fr>0.8 (spillthrough abut.) & 1.88 & ERR & 2.01 & 1.89 & ERR & 2.01 \\
\hline
\end{tabular}

